\title{
TroyAcademy
}

International Journal of Social Sciences

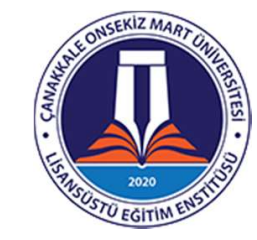

\section{Yükseköğretim Kurumlarında Disiplin Amirleri ve Disiplin Kurulları Sorunları Üzerine Nitel Bir Araştırma}

\author{
Araştırma Makalesi/Research Article
}

\author{
Hüseyin ERKUL* Ayşe ÖZCAN BUCKLEY** Hafize SEÇTİM***
}

\section{ÖZET}

Disiplin, kişilerin kamu hizmetlerini düzenleyen yasalara ve kurallara, toplumun genelinin düşünce ve davranışlarına uymaları için alınan önlemlerin bütünü olarak ifade edilmektedir. İdare, bir ihlalin varlığında idari usûllere göre disiplin cezaları uygulamaktadır.

Araştırmada yükseköğretim kurumlarında disiplin amirleri ve disiplin kurullarında yaşanan disiplin hukuku sorunlarının belirlenmesi amaçlanmıştır. Araştırma betimsel (descriptive) nitelikte bir araştırma olup, araştırma kapsamında, görüşme tekniği ile toplanan veriler içerik analizi ile çözümlenmiştir. Araştırma sonucunda Yükseköğretim kurumlarında görev yapan disiplin amirleri ve disiplin kurullarının, disiplin hukuku konusunda bilgi ve deneyim eksikliği olduğu, soruşturmalarda usûl hataları yapıldığı saptanmıştır. Araştırma sonucunda sorunlara yönelik "Soruşturma Değerlendirme Komisyonu (SDK)" önerisi sunulmuştur.

Anahtar Kelimeler: Disiplin, Disiplin Hukuku, Disiplin Amiri, Disiplin Kurulları, Yükseköğretim Kurumları

\section{A Qualitative Research on the Problems of Disciplinary Superiors and Disciplinary Boards in}

\section{Higher Education Institutions}

\begin{abstract}
Discipline is expressed as the whole of the measures taken to ensure that people comply with the laws and rules regulating public services, and the thoughts and behaviors of the general public. In the presence of a violation, the administration applies disciplinary penalties according to administrative procedures.

In the research, it is aimed to determine the disciplinary law problems experienced in disciplinary superiors and disciplinary boards in higher education institutions. The research is a descriptive (descriptive) short research, and within the scope of the research, the data collected by the interview technique and were analyzed by content analysis. As a result of the research, it was determined that the disciplinary superiors and disciplinary boards working in higher education institutions lacked knowledge and experience in disciplinary law, and procedural errors were made in the investigations. As a result of the research, a proposal for the "Investigation and Evaluation Commission (SDK)" was presented.
\end{abstract}

\footnotetext{
* Prof. Dr. ÇOMÜ Siyasal Bilgiler Fakültesi Siyaset Bilimi ve Kamu Yönetimi Bölümü, hcerkul@comu.edu.tr, hcerkul@comu.edu.tr, ORCID No: 0000-0002-8856-696X

** Prof. Dr. Giresun Üniversitesi, İktisadi ve İdari Bilimler Fakültesi Siyaset Bilimi ve Kamu Yönetimi Bölümü, ayoz_61@hotmail.com, ORCID No: 0000-0002-1030-6631

*** Dr. ÇOMÜ Lisansüstü Eğitim Enstitüsü, Kamu Yönetimi Doktora Programı Mezunu, sectimhafize@gmail.com, ORCID No: 0000-0001-8671-0828
} 
Keywords: Discipline, Disciplinary Law, Disciplinary Superior, Disciplinary Boards, Higher Education Institutions

\section{GíRiş}

Kamu görevlilerinin kamu hizmetlerini gereği gibi yürütmesini sağlamak amacı ile başta Anayasa olmak üzere kanunların ve yönetmeliklerin Devlet memuru olarak emrettiği ödevleri yurt içinde veya dışında yerine getirmeyenlere, uyulmasını zorunlu kıldığı hususları yapmayanlara, yasakladığı işleri yapanlara durumun niteliğine ve ağırlık derecelerine göre disiplin işlemleri uygulanmaktadır ve bu işlemler meslek yaşamında sıkça karşılaşılan bir olgudur.

Devlet, genel idare esaslarına göre yürütmekle yükümlü olduğu kamu hizmetlerinin gerektirdiği asli ve sürekli görevlerin kamu görevlilerince yerine getirilmesi için bir yandan kamu kurumları kurarken öte yandan yasal ve yönetsel düzenlemeler getirerek, hukuk devleti ilkesine uygun olarak, işyeri düzenini ve kamu düzenini sağlar.

Kamu kurumlarında işyeri düzeninin sağlanmasında genel kanun olarak 657 sayılı Devlet Memurları Kanunu ve bu Kanuna dayalı çıkarılan yönetmelikler uygulanırken, özel kanunları bulunan kurumlar için ayrı düzenlemeler bulunmaktadır. Bu kurumlardan biri de yükseköğretim kurumlarıdır.

Yükseköğretim kurumlarında teşkilatlanma ve işleyiş 2547 sayılı Yükseköğretim Kanunu ile düzenlenmiştir. $\mathrm{Bu}$ Kanunun 53. maddesi disiplin ve ceza işleriyle ilgili genel esasları belirlemektedir.

Yükseköğretim kurumlarında görev yapan kamu görevlileri idari personel ve akademik personel olarak ikiye ayrılmaktadır. Disiplin hukuku açısından akademik personel, özel Kanun olan 2547 sayılı Yükseköğretim Kanunu ve 2914 sayılı Yükseköğretim Personel Kanunu'na tabi iken, idari personel çerçeve kanun olan 657 sayılı Devlet Memurları Kanunu'na tabidir. Bu farklılık; ceza soruşturmaları, disiplin amirleri ve disiplin kurulları gibi konuları takip eden süreçlerde yaşanan bazı hukuksal sorunlar nedeniyle zaman zaman derinleşebilmekte ve adalet kavramının zedelenmesine yol açmaktadır. Oysa ki Yükseköğretim kurumlarında disiplin amirleri ve disiplin kurullarında yaşanan disiplin hukuku sorunlarının çözümlenmesi; başta adaletin tesisi olmak üzere kamu düzeninin ve işyeri düzeninin sağlanmasında, toplumsal barış ve kurumsallaşma açısından da büyük önem arz etmektedir. Bu kapsamda araştırmacıları bu çalışmayı yapmaya teşvik eden en temel nokta, yükseköğretim kurumlarında disiplin hukuku açısından disiplin amirlerinde ve disiplin kurullarında yaşanan hukuksal sorunlar hakkında ayrıntılı bir durum analizinin yapılma ihtiyacının görülmesidir. Durum analizi kapsamında sorunların saptanması ve bu sorunlara yönelik çözüm önerilerinin sunulması çalışmanın çıkış noktası ve ana amacıdır. 
Araştırma şu hipotez (denence) üzerine yapılandırılmıştır: "yüksseköğretim kurumlarında görev yapan disiplin amirleri ve disiplin kurulları, disiplin hukuku konusunda eğitim ve bilgi eksikliği, mevzuatın sık değişmesi ve karıştırılması, eksik incelemeye dayalı soruşturma raporlarının hazırlanması ile deneme-yanılma kaynaklı usul hataları gibi nedenlerden dolayı işyeri düzenini olumsuz olarak etkilemektedir."

Araştırmada öncelikle betimsel nitelikte bir içerik analizi ile yükseköğretim kurumlarındaki disiplin amirleri ve disiplin kurullarında yaşanan sorunlar saptanmaya ve sorunların niteliğini belirlenmeye ve yorumlanmaya çalışılmaktadır. Böylece disiplin amirlerinin yaşadıkları ve disiplin kurullarında yaşanan sorunların kuramsal zemini oluşturulmuştur. İkinci aşamada ise, üniversiteler özelinde disiplin amirleri ve disiplin kurulları üyelerinden görüşme tekniğiyle toplanan veriler MAXQDA programında araştırmanın amacına uygun olarak açık kodlar ve kategoriler üzerinden, seçici kodlama yapılarak analiz edilmekte ve yorumlanmaktadır. Çalışma, yaşanan sorunları yukarıda ifade edilen konularla sınırlandırarak, verileri adalet ve disiplin ilişkisi çerçevesinde ele almaktadır. İlgili yasal ve yönetsel düzenlemeler de bu kapsamda değerlendirmeye dahil edilmektedir.

\section{KURAMSAL VE KAVRAMSAL CERCEEVE}

Çalışmada öncelikle bir durum saptaması yapılmakta ve disiplin amirlerinin yaşadıkları ve disiplin kurullarında yaşanan sorunların nedenleri ve bunların neler olduğu incelenmektedir. İkinci olarak, yapılan saptamaların 1şı̆ğında kurulan denenceyi (hipotezi) sınamak amacıyla uygulayıcılardan bilgiler toplanmış ve toplanan bilgiler anlama, açıklama ve neden-sonuç ilişkisi açısından değerlendirilmiştir. Son olarak elde edilen bulgular yorumlanarak genelleme yapılmaya çalış1lmıştır.

\subsection{Kavram Tanımları}

Anayasaya göre kamu düzeni, Devletin temel görevlerinden sayılan ve toplum düzeninin sağlanması için bireylerin ve toplumun refahı, huzuru, güvenliği, esenliği ve sağlı̆̆ının korunması; maddi ve manevi varlığının gelişmesi için şartları hazırlayan ekonomik ve toplumsal kurallar bütünüdür. $\mathrm{Bu}$ kapsamda kamu görevlisi ise, hukuki durumlarına ve yaptıkları görevin niteliğine bakılmaksızın, kamu kesiminde veya Devletin bütün organlarında görev yapan herkesi ifade etmektedir. $\mathrm{Bu}$ anlamda Cumhurbaşkanından kamuya ait bir fabrikada çalışan işçiye kadar herkes kamu görevlisi olarak nitelendirilebilir (Günday, 2011: 580).

Yükseköğretim kurumları, bir toplumun ilerlemeci bir yapıya kavuşmasında ve toplumun farklı alanlarında farklı düzeylerde entelektüelliğin oluşmasında önemli işlevler yüklenmiş yapılardır ve üniversite eğitim-öğretiminin sunulduğu ortamlardır. Bu yapılar -özel veya kamu sektörü- ayrıca kamu düzeninin sağlanmasında da önemli roller üstlenmektedir. 2547 sayılı Kanun’a göre (md.3/a) 
Yükseköğretim Kurumları ile anlaşılması gereken üniversiteler ile yüksek teknoloji enstitüleri ve bunların bünyesinde yer alan fakülteler, enstitüler, yüksekokullar, konservatuvarlar, meslek yüksekokulları ile uygulama ve araştırma merkezleridir.

Üniversite ise, bilimsel özerkliğe ve kamu tüzel kişiliğine sahip yüksek düzeyde eğitim-öğretim, bilimsel araştırma, yayın ve danışmanlık yapan, fakülte, enstitü, yüksekokul vb. kuruluş ve birimlerden oluşan bir yükseköğretim kurumudur (2547/3/d).

Disiplin; bir topluluğun yasalara ve düzenle ilgili kurallarına uyulması, kişilerin içinde yaşadıkları topluluğun genel düşünce ve davranışlarına uymalarını sağlamak amacıyla alınan önlemlerin bütünüdür. Bir topluluğun yasalarına ve düzenle ilgili yazılı ve yazısız kurallarına titizlik veya özekle uyulması durumu, sıkı düzen zapturapt olarak açıklanmaktadır (sozluk.gov.tr, 2021).

Disiplin Amiri; kamu görevlilerinin disipline aykııı davranışlarında disiplin soruşturması yaptırarak disiplin cezası vermeye yetkili kişidir.

657 sayılı Kanunda doğrudan disiplin amiri tanımlanmamış, disiplin cezası vermeye yetkili amir ve kurullar ortaya konmuştur.

Disiplin Kurulu; disiplin soruşturması işlemlerinde kademe ilerlemelerinin durdurulması cezası teklifini ve disiplin cezalarına karşı itirazları değerlendiren, fakülte ve üniversite yönetim kurulu üyelerinden oluşturulan kuruldur.

Adalet; hak ve hukuka uygunluk; hak ve hukuku gözetme ve yerine getirme; doğruluk anlamlarına gelmektedir.

İşyeri düzeni; iş ve hizmet üretmek amacıyla oluşturulmuş mekanlarda insan ilişkilerinin düzenlenmesi, konulmuş kuralların uygulanması ve uyulması çalışma ortamının işin ve hizmetin niteliklerine göre oluşturulması ve bir sistem ve işleyişin gerçekleştirilmesidir.

Kurumsal barış; çatışma ve stresin en aza indirildiği, adalet ve eşitlik ilkelerinin sağlandığı ortamdir.

Kurumsallaşma; bir kurumun sunduğu hizmetleri kalite ve nitelikli personeli geliştirme faaliyetleri bağlamında en uygun yapı ve işleyişe ulaşması.

\subsection{Literatür Özeti}

Konuya ilişkin oldukça kapsamlı bir literatür ile karşılaşmak mümkündür, ancak bu literatür özellikle disiplin mevzuatı, disiplin soruşturmaları gibi konular üzerine yapılandırılan ve yükseköğretimin içeriğini, kalitesini, yöntemlerini tartışan çalışmalardan oluşmaktadır (Akyılmaz, 2000; Çınarlı, 2011; Demircioğl1, 2014; Bucaktepe, 2015; Arpacığlu, 2015; Gürgen, 2018; Ayturan, 2018; Turhan, 2019; Erdoğan, 2019). 
Disiplin amirleri ve disiplin kurulları çalışma sisteminde ortaya çıkan sorunların betimsel analizi ve bunlara yönelik çalışmalar ise daha dar kapsamlı bir çerçeveyi oluşturmaktadır. YÖK ulusal tez merkezi üzerinden yapılan online taramada “disiplin amiri” kavramı ile sadece bir adet yüksek lisans tezi saptanmıştır. "Disiplin kurulları veya disiplin kurulu” kavramları ile yapılan taramada ise 2 adet yüksek lisans tezine ulaşılmıştır. Ancak bu çalışmaların bir kısmı doğrudan yükseköğretim kurumlarının disiplin amirlerine ve disiplin kurullarına yönelik değildir.

Çalışma konusuyla doğrudan ilgili belli başlı çalışmalar burada kısaca değerlendirilmektedir. Bunlardan birisi Duman'ın (2012) "Yükseköğretim Ceza ve Disiplin Soruşturması” başlıklı çalışmasıdır. Çalışma, disiplin ve ceza hukukunun temel niteliklerini ortaya koymuş, ilgili mevzuata ve örnek yarg1 kararlarına yer vermiştir. Ancak Yükseköğretim Kurumları Yönetici, Öğretim Elemanı ve Memurları Disiplin Yönetmeliği mülga olduğundan kitap çalışması 2021 yılında meri mevzuata göre yeniden düzenlenmiş ve güncellemiştir.

"Yükseköğretim Kurumlarında Disiplin Soruşturması Sorunu ve Almanya Disiplin Mahkemeleri Önerisi” başlıklı çalışmasında Çınarlı (2011); disiplin yönünden kamu personelinin işlediği suçlar için verilen cezaların çoğu kez idare mahkemeleri tarafından soruşturma esas ve yöntemlerine uygun olmaması gibi nedenlerle iptal edildiğini vurgulamış, Türkiye’de yükseköğretim kurumlarında uygulanan disiplin soruşturma yöntemlerini, Alman idare hukukunda özel ihtisas mahkemeleri olan disiplin mahkemelerinin soruşturma yöntemleri ile kıyaslayarak incelemiştir. Alman idare hukukunda disiplin soruşturmaları, disiplin alanında uzmanlaşmış hâkimler tarafından yürütüldüğ̈nü, böylece hata ve hak ihlalleri oranının düştüğünü belirten araştırmacı, yükseköğretim kurumları için de Alman hukukundaki disiplin mahkemeleri modelini önermiştir. Sonuç olarak; disiplin soruşturmaları ve verilen cezaların hâkimler tarafından nesnel bir şekilde yapılabileceğine dikkat çekmiştir.

Mesci ve Aydın (2017) ise "Yükseköğretim Kurumlarında Çalışan Kamu Görevlilerinin Ceza Soruşturma Usülü” başlıklı çalışmalarında; 2016 tarih ve 6764 sayılı Kanun ile 2547 sayılı Yükseköğretim Kanunun 53. maddesinde yapılan değişikliği incelemişler ve yükseköğretim kurumlarında doğrudan soruşturma açılması yerine öncelikle ön inceleme başlatılmasının gereksiz soruşturma açılmasını önleyebileceği, böylece karar vermeye yetkili olan kurulların ve yargının yükünü hafifletilebileceği, personelin gereksiz yere açılan soruşturmalarla yıpratılmasının da önüne geçilebileceğini belirtmişlerdir. Bununla birlikte araştırmacılar, 2547/53. maddesi gereğince tüm akademik ve idari personel hakkında ilk soruşturmanın kurum içerisinde yapıldığı ancak, son soruşturmanın kurum içinden ve kurum dışından belirlenen kurullarca yapılan ikili bir ayrıma gidildiği; soruşturmanın ve kovuşturma kararının büyük oranda bu konuda eğitim almamış kişi ve kurullarca yapılmasının sorunlara yol açabildiği; soruşturmanın tamamlanması için gerekli olan 
sürelerin tespitinin yapılmadığı; itirazın yapılacağı mercii ve itiraz süresine ilişkin hükümlerin olmadığı; 2547 sayılı Kanunu'nun disiplin ve ceza ile ilgili hükümlerinin güncelliğini kaybettiği, yeni bir düzenlemenin yapılmasının yerinde olacağı sonucuna ulaşmışlardır.

Yılmaz'ın (2013), Yükseköğretim Kanunu'nda öngörülen düzenlemelerin ceza soruşturma uygulamalarında birtakım sıkıntılara yol açtığı, bunun pek çok sebebi olduğu; 2547 sayılı Yükseköğretim Kanunu'nun 53. maddesinde ceza soruşturması usulünün ayrıntılı olarak düzenlenmediği; diğer Kanunlara yapılan atıfların mevzuat değişiklikleri göz önüne alınarak güncellenmediği, Yükseköğretim sistemindeki yeni uygulamaların mevzuata eksik uyumlandığı ya da unutulduğu; ceza soruşturması sürecine yönelik düzenlemelerin diğer kanunlar ve uygulamaları dikkate almak suretiyle bir kez daha gözden geçirilmesi gerektiği; uygulamadaki sorunlar ve bunlara getirilmiş çözüm yolları da dikkate alınarak, mevzuata eklenmesi gerektiği sonucuna ulaşmıştır.

Erkul, Kanten ve Aydın (2019) yaptıkları ortak çalışmada; yöneticilerin sıklıkla karşılaştıkları bir yönetsel işlem olarak disiplin ve ceza soruşturmalarını incelemişler ve örneklere yer vermişlerdir. $\mathrm{Bu}$ kapsamda yazarlar, kurumlarda yaşanan hukuksal sorunların en aza indirilmesinde; olumlu örgüt ikliminin oluşturulmasının, yöneticilerin adil ve hukuka uygun davranmasını ve hukuksal sorunlar çıktığında araştırmak üzere profesyonel soruşturmacıların görevlendirilmesi gerektiğini belirtmişlerdir.

Seçtim ve Erkul (2020) çalışmalarında özellikle şu konulara dikkat çekmişlerdir: Yükseköğretim kurumlarında görev yapan akademik personelin ceza soruşturmaları 2547 sayılı Yükseköğretim Kanunu'nun 53. maddesi (c) fikrası ile düzenlendiği, bununla birlikte ceza soruşturmalarının yürütülmesi ve karar aşamasında 2577 sayılı İdari Yargılama Usul Kanunu ve 5237 sayılı Türk Ceza Kanunu'nun iyi bilinmesi gerektiği, ilgili kanunların yöneticiler ve soruşturmacılar tarafindan yeterince bilinmemesi nedeniyle eksik inceleme, usûl hatası, illiyet bağı kurulamaması, yetkisiz kurul ve neden (gerekçe)-konu (karar) ortaya konulamaması hem adaletin tecellisinin geciktiği hem de maddi-manevi zararlara yol açtı̆̆ı konuları yazarların incelemeleri sonucu ortaya koydukları sonuçlardır.

Ercan (2019), yüksek öğretim personeline uygulanacak olan disiplin hukukuna ilişkin çeşitli sorunların gündemde olduğunu; uygulamada hukuk birliğinin sağlanamadığını, yasal düzenlemelerdeki belirsizlikler ve çelişkilerin giderilmesi gerektiğini ve idare hukuku alanında usûl kuralları bakımından hukuk birliği sağlanabilmesi içim bir idari usul kanununa ihtiyaç duyulduğunu belirtmiştir.

Bucaktepe (2015) ise yöneticilerin çalışma ortamında olumlu örgüt iklimini oluşturmalarının, olumsuz davranışların azaltılmasında önemli olduğunu, Türk İdare Hukukunda disiplin cezalarının genellikle disiplin amiri ya da atamaya yetkili amir gibi tek bir irade tarafından verildiği, bu 
uygulamanın memurun güvenliğini zayıflatabileceği dolayısıyla disiplin cezasının verilmesinde kurulların yetkilerinin arttırılmasının devlet memurunun lehine bir yaklaşım olacağı konularına dikkat çekmektedir.

Erdoğan (2019), “2547 Sayılı Yükseköğretim Kanunu Çerçevesinde Yükseköğretim Kurumlarında Akademik ve İdari Personele Uygulanan Disiplin Soruşturmasının Hukuki Niteliği ve Usulü" başlıklı yüksek lisans tez çalışmasında, 2547 sayılı Kanun'daki belirsizliklere, disiplin soruşturmalarında yapılan usûl hataları ve eksikliklere, disiplin amir ve disiplin kurullarında yaşanan sorunlara değinmiş, yaşanan sorunların çözümüne yönelik 2547 sayılı Kanunda yapılacak bazı öneriler sunmuştur.

Sonuç olarak; yapılan çalışmaların genel olarak mevzuattaki belirsizliklere, soruşturmalarda karşılaşılan sorunlara, soruşturmacıların yetkinliğinin önemine, karar örnekleriyle disiplin ve ceza soruşturmaları sonucunda yapılan hataları ortaya koymaya, yöneticilerin ve disiplin amirlerinin olumlu örgüt iklimi oluşturma ve adaletin sağlanmasındaki önemine odaklandığ1 görülmüştür.

\section{YÜKSEKÖĞRETIM KURUMLARINDA DISSIPLIN AMIRLERİ VE DİSIPLİN KURULLARI}

Yükseköğretim kurumlarında disiplin amirleri ve disiplin kurullarında yaşanan disiplin hukuku sorunlarının belirlenmesi için öncelikle disiplin mevzuatının ve konuya ilişkin kurumsal içeriğin tartışılması gerekmektedir. Bu kapsamda aşağıdaki başlıklarda sırasıyla mevzuat, kurumsal ve örgütsel içerik genel hatlarıyla değerlendirilmektedir.

\subsection{Yükseköğretim Kurumları Disiplin Mevzuatı}

Çalışma kapsamında Yükseköğretim Kurumları disiplin genel mevzuatı olarak, Anayasa, 657 sayılı Devlet Memurları Kanunu, 4483 sayılı Memurlar ve Diğer Kamu Görevlilerinin Yargılanması Hakkında Kanun, Devlet Memurları Disiplin Yönetmeliği; özel mevzuat olarak ise 2547 sayılı Yükseköğretim Kanunu, 2547 sayılı Kanunun 53. maddesinde değişiklik yapan 7243 sayılı Kanun ve 6764 say1lı Kanun incelenmektedir.

T.C. 1982 Anayasasının 128. maddesi kamu görevlilerini tanımlamış ve 129. maddesinde de memurlar ve diğer kamu görevlilerine savunma hakkı tanınmadıkça disiplin cezası verilemeyeceği belirtilmiştir.

657 say1lı Devlet Memurları Kanunu'nun 124. maddesi disiplin amirleri, 125. maddesi disiplin cezalarının çeşitleri ile ceza uygulanacak fiil ve halleri düzenlemiştir. 126. maddesinde disiplin cezası vermeye yetkili amirler ve disiplin kurulları belirlenmiştir. 129. maddesinde de yüksek disiplin kurullarının karar usûlü açıklanmıştır. 
Yükseköğretim kurumlarının idari personeli için genel kanun olan 657 sayılı Devlet Memurları Kanunu, 4483 sayılı Memurlar ve Diğer Kamu Görevlilerin Yargılanması Hakkında Kanun ve Devlet Memurları Disiplin Yönetmeliği uygulanırken akademik personel için özel kanun olan 2547 sayılı Yükseköğretim Kanununun 53. maddesi uygulanmaktadır.

2547 sayılı Kanunun 53. maddesi disiplin ve ceza işleri başlı̆ğ altında (a) fikrasında YÖK Başkanının Yüksek Öğretim Kurulu ile üniversite rektörlerinin; rektörün üniversitenin; dekanın fakültenin; enstitü ve yüksekokul müdürlerinin enstitü ve yüksekokulların; bu birimlerin genel sekreter veya sekreterlerinin de sekreterlik personelinin disiplin amirleri olduğu belirtilmiş, (b) fıkrasında öğretim elemanları, memur ve diğer personelin disiplin işlemleri, disiplin amirlerinin yetkileri, devlet memurlarına uygulanan usûl ve esaslara göre YÖK tarafindan düzenleneceği ortaya konmuş, (c) fikrasında ise ceza soruşturma usulü: 1. bendinde ilk soruşturma, 2. bendinde son soruşturmanın açılıp açılamaması, 3. bendinde Ceza İşleri Son Soruşturma Kurulu (CISSKK) toplanma usulü, 4. bendinde men-i muhakeme ve lüzum-u muhakeme kararlarının Danıştay tarafından incelenmesi, 5. bendinde de değişik statüdeki kişilerin birlikte suç işlemeleri halinde soruşturma usulü ve yetkili yargılama merciinin görev itibariyle üst dereceliye göre tayin olacağ 1 açıklanmıştır.

6764 sayılı Kanunun 26-35. maddeleri 2547 sayılı Kanunun 53. maddesinde değişiklikler ve eklemeler yapmıştır. Bu Kanunla 2547/53-(a) ve (b) fikrası değiştirilmiş (b) fikrasına yükseköğretim kurumlarının öğretim elemanları, memur ve diğer personeline uygulanabilecek disiplin cezaları; uyarma, kınama, aylıktan veya ücretten kesme, kademe ilerlemesinin durdurulması veya birden fazla ücretten kesme, üniversite öğretim mesleğinden çıkarma ve kamu görevinden çıkarma cezaları biçiminde sıralanmıştır.

6764 sayılı Kanunda uyarma, kınama, aylıktan veya ücretten kesme, kademe ilerlemesinin durdurulması ve birden fazla ücretten kesme, üniversite öğretim mesleğinden çıkarma ve kamu görevinden çıkarma ve cezalarıyla ilgili düzenlemeler getirilmiş ancak; Anayasa Mahkemesi'nin EN: 2017/33, KN:2019/20 kararıla bu cezalardaki 1, 2, 3, 4 ve 6 numaralı bentlerinde yer alan "657 sayılı Kanundaki fiillere ilave olarak ... ibaresi Anayasaya aykırı olduğu gerekçesiyle iptal edilmiştir. 6764 sayılı Kanunda 2547/53. maddesine A fikrasıyla savunma hakkı, B fikrasıyla görevden uzaklaştırma, C fikrasıyla disiplin cezası verme yetkisi, D fikrasıyla disiplin cezası verilmesinde uygulanacak temel ilkeler, E fikrasıyla özlük dosyasında saklama konuları eklenmiştir.

7243 sayılı Yükseköğretim Kanunu ile bu Kanunda Değişiklik Yapılmasına Dair Kanunla 2547 sayılı Yükseköğretim Kanunun 53. madde (a) fikrasında ve Ç fikrasında değişiklik yapılmış; 1609 
sayılı Kanun ibaresi; 3628 sayılı Kanun şeklinde değiştirilmiş; iş sözleşmesiyle çalışan personelin 4857 sayılı Kanuna tabi olduğu belirtilmiş; memurlar hakkında 657 DMK/125. maddesinin uygulanacağ1 vurgulanmış; disiplin cezalarına ek bentler konulmuş ve 2547/53-E değiştirilmiştir.

\subsection{Disiplin Amirleri}

Disiplin amirleri 657 sayılı Devlet Memurları Kanunun 124. maddesinde; kurumların kuruluş ve görev özellikleri dikkate alınarak özel yönetmeliklerinde tayin ve tespit edilecek amirler olarak ortaya konmuştur.

Devlet Memurları Disiplin Yönetmeliğinin 4. maddesinde; disiplin amirlerinin üst yöneticilerin başında bulundukları kamu idarelerinde veya kendilerine bağlı birimlerde; diğer disiplin amirlerinin kamu idarelerinin kuruluş ve görev özelliklerine göre hazırlanan ve yürürlüğe konulan özel yönetmeliklerle tespit edileceği belirtilmiştir.

Yükseköğretim kurumlarında 2547 sayılı Yükseköğretim Kanununun 53. maddesi (a) fikrasında değişiklik yapan 6764 sayılı Kanunda rektör üniversitenin, dekan fakültenin, enstitü ve yüksekokul müdürü enstitü ve yüksekokulların, genel sekreter veya sekreterler bağlı birim personelinin disiplin amirleri olarak tanımlanmışlardır.

\subsection{Disiplin Kurulları}

Disiplin kurulları 657 sayılı devlet Memurları Kanununun 126. maddesinde kademe ilerlemesinin durdurulması cezasının, memurun bağlı olduğu kurumdaki disiplin kurulunun kararı alındıktan sonra atamaya yetkili amirler, il disiplin kurullarının kararına dayanan hallerde Valiler tarafından verileceği; devlet memurluğundan çıkarma cezasının amirlerin bu yoldaki isteği üzerine, memurun bağlı bulunduğu kurumun yüksek disiplin kurulu kararı ile verileceği; disiplin kurulu ve yüksek disiplin kurulunun ayrı bir ceza tayinine yetkisi olmadığı, cezayı kabul veya reddedeceği, ret halinde atamaya yetkili amirler tarafından 15 gün içinde başka bir disiplin cezası vermekte serbest oldukları belirtilmiştir.

Devlet Memurları Disiplin Yönetmeliğinin 8. maddesinde kamu idarelerinin merkez teşkilatlarında bir yüksek disiplin kurulu ve taşra teşkilatları için illerde müşterek bir il disiplin kurulu kurulacağı; disiplin kurulunun bir başkan ve dört üye ile varsa memurun üyesi olduğu sendikanın temsilcisinden oluşacağ 1 biçiminde düzenlenmiştir.

Yükseköğretim kurumlarındaki disiplin kurulları 2547 sayılı Yükseköğretim Kanununun 53. maddesine ekleme yapan 6764 sayılı Kanunla 2547/53. maddesi E fikrası disiplin kurullarının teşekkülünü ortaya koymaktadır. Bu fikraya göre; Yüksek Disiplin Kurulu Yükseköğretim Genel Kuruludur. Üniversite disiplin kurulu rektör dışındaki üniversite yönetim kurulu üyelerinden oluşur; 
kurula akademik olarak en kıdemli profesör üye başkanlık eder. Üniversite bağlı birimlerin yönetim kurulları aynı zamanda disiplin kurulu olarak görev yapar. Bu birimlerin disiplin kurullarında dekan veya müdür yer alamaz.

Bu durumda ilgili disiplin kuruluna kurul üyelerinden en yüksek unvanlı öğretim üyesi, en yüksek unvanlı öğretim üyesinin birden fazla olması halinde en kıdemli üye, öğretim üyesi bulunmaması halinde en kıdemli öğretim görevlisi başkanlık eder.

Yükseköğretim Kurulu personeli için disiplin kurulu, Genel Sekreterin başkanlığında, Birinci Hukuk Müşaviri ile Personel, Strateji Geliştirme, İdari ve Mali İşler Daire başkanlarından teşekkül eder.

Yüksek Disiplin Kurulu hariç, disiplin kurullarında profesörlerle ilgili hususların görüşülmesinde doçent ve doktor öğretim üyesi, doçentlerle ilgili hususların görüşülmesinde doktor öğretim üyeleri ve kendileri ile ilgili hususların görüşülmesinde ilgili üyeler görüşmelere katılamazlar.

Herhangi bir sebeple disiplin kurullarının teşekkül edememesi halinde eksik üyelikler eşdeğer unvana sahip öğretim üyeleri arasından senato tarafından belirlenen üyelerce tamamlanır.

\subsection{Disiplin Amirleri ve Disiplin Kurullarıyla İlgili Bazı Danıştay Kararları Özeti}

(1) Danıştay 12. Dairesi EN: 2009/4526, KN: 2012/1924 sayılı kararı: "Hakkında disiplin soruşturması yürütülen memurun üyesi olduğu sendikanın temsilcisinin de kurullarda yer alacağı".

(2) Danıştay 1. Dairesi EN: 2011/2206, KN: 2012/402 sayılı kararı; "Değişik statüde kişilerin birlikte suç işlemeleri halinde, son soruşturmanın açılıp açılmamasına karar verecek kurulun, görev itibariyle üst derecede bulunana göre oluşturulacağı".

(3) Danıştay 1. Dairesi EN: 2010/1936, KN: 2010/2123 sayılı kararı: "Yetersiz ve eksik incelemeye dayalı ön inceleme raporunun yetkili mercii kararına esas alınmayacağı”.

(4) Danıştay IDDK EN: 2007/1846, KN: 2011/66 sayılı kararı: “savunma alınmadan disiplin cezası verilemeyeceğì".

(5) Danıştay 12. Daire EN: 2008/7024, KN: 2011/1314 sayılı karar: "Hakkında disiplin soruşturması açılan kamu görevlisinin savunması alınırken disiplin suçunu oluşturan eyleminin açık bir şekilde belirlenmesi, hangi disiplin kurallarını ihlal ettiğinin ortaya konulması gerektiği”.

(6) Danıştay IDDK EN: 2006/2042, KN: 2010/448 sayılı kararı: “Araştırma Görevlisine disiplin cezasının disiplin amiri olan dekan tarafından verilmesi gerekirken, rektör tarafından verilen cezada yetki yönünden hukuka uyarlık bulunmadığı”. 
(7) Danıştay 1. Dairesi EN: 2010/101, KN: 2010/207 sayılı kararı: "Şikâyet konusu eylemle illiyet bağı bulunmayan şüpheli hakkında 2547/53. madde uyarınca bir karar alınamayacağı”.

(8) Danıştay 1. Dairesi EN: 2009/1503, KN: 2009/1722 sayılı kararı: "Soruşturmada şüphelinin adı soyad1, kimliği, görevi, görev yeri gibi hususlar belirlenerek ve iddia konularıyla ilgili illiyet bağ1 bulunan bütün şüphelilerinde savunmalarının alınması, iddialarla ilgili tüm delillerin toplanması gerekiyorsa bilirkişi incelemesi yaptırılması...".

(9) Danıştay 1. Dairesi EN: 2007/1500, KN: 2008/129 sayılı kararı: “üniversitede şüphelilerin 657 sayılı DMK'na tabi memur olarak görev yapmaları nedeniyle 2547/53/c 2-e uyarınca haklarında İl İdare Kurulunca karar verilmesi gerektiğii”.

(10)Danıştay 5. Dairesi EN: 2016/17762, KN: 2017/24014 sayılı kararı: "Davacının işlediği kabul edilerek cezalandırılmasına dayanak alınan eylemi yönünden ayrıca bir soruşturma yapılmadığı, Yüksek Disiplin Kurulu aşamasında saptanan fiil yönünden yeni bir soruşturma oluru alınarak davacı lehine ve aleyhine olan tüm deliller araştırılmadan, bu fiillere ilişkin savunması alınmadan tesis edilen işlemde hukuka uyarlık bulunmadığı” (emsal.danistay.uyap.gov.tr).

Danıştay kararları 1şığında disiplin soruşturmalarında genel olarak soruşturmanın yetkisiz kurullarca değerlendirilmesi, savunma alınmaması, sendika temsilcilerini bulundurulmaması, suç ile illiyet bağı kurulmaması, gerekçe ortaya konmadan ceza verilmesi, zaman aşımının dikkate alınmaması, eksik inceleme yapılması gibi usûl ve esasların gözden kaçırılarak gerçekleştirildiği görülmektedir. Dolayısıyla disiplin soruşturmalarında güncel mevzuatı iyi bilmeyen, yetkin olmayan soruşturmacılara görev verildiği ortaya çıkmaktadır.

\section{ALAN ARAŞTIRMASI}

Yükseköğretim kurumlarında disiplin hukuku açısından disiplin amirlerinin ve disiplin kurullarının yaşadığı hukuksal sorunlar maddi ve manevi birçok olumsuz sonuç ortaya çıkarmaktadır. Çalışmada yükseköğretim kurumlarında disiplin hukuku açısından ortaya çıkan sorunlar hakkında durum tespiti yapmak ve bu sorunlara yönelik çözüm önerileri sunmak amaçlanmıştır. Böylece araştırma, yükseköğretim kurumlarındaki disiplin amirleri ve disiplin kurullarında yaşanan sorunları belirlemeye yönelik bir anlama ve tanımlamayı hedefleyen bir betimsel analiz temelinde ilerlemiştir.

\subsection{Araştırmanın Örneklemi}

Araştırmanın örneklemini yükseköğretim kurumlarında disiplin amiri ve disiplin kurulu üyesi olarak görev yapan 17 kişi oluşturmaktadır. Araştırmada veri doygunluğu ve yeterliliği kriteri esas alınarak amaçlı örnekleme yöntemi kullanılmıştır. Bu doğrultuda dekan, enstitü müdürü, yüksekokul müdürü, genel sekreter, fakülte sekreteri olarak görev yapan 17 kişi ile görüşmeler yapıldıktan sonra veri doygunluğu ve veri yeterliliği sağlandığına kanaat getirilmiştir. 


\subsection{Veri Toplama Tekniği}

Araştırmanın verileri yarı yapılandırılmış görüşme formu kullanılarak görüşme tekniği ile toplanmıştır. Disiplin soruşturmaları ve yaşanılan sorunlara yönelik yapılmış çalışmalar incelenerek 20 adet açık uçlu soru ile konu açıklanmaya çalışılmıştır. Görüşmeler katılımcıların ofislerinde önceden randevu alınarak 35-45 dakika arasında gerçekleştirilmiş ve not tutularak kaydedilmiştir.

\subsection{Verilerin Analizi}

Araştırmada üniversiteler özelinde disiplin amirleri ve disiplin kurullarından görüşme tekniğiyle toplanan veriler MAXQDA programında araştırma amacına uygun olarak açık kodlar ve kategoriler oluşturularak ardından seçici kodlama yapılarak içerik analizi ile çözümlenmiştir.

\section{BULGULAR VE TARTIŞMA}

Araştırmada elde edilen bulgular doğrultusunda açı kodlar oluşturulmuştur. Buna göre kodlar arasındaki ilişkilerin oluşturduğu yapı sonucunda 13 adet kategori ve 903 açık kod belirlenmiştir. Bu kodların görselleşmesinde frekans (f) tablo ve grafikleri, yoğunluk tabloları ve kod haritaları kullanılmıştır.

13 adet kategori şöyle sıralanabilir: (1) Disiplin amirinin sahip olması gereken özellikler, (2) Disiplin amirlerinin bilgi eksiklikleri, (3) Karşılaşılan disiplin konuları, (4) Disiplin soruşturmalarında dikkat edilmesi gereken hususlar, (5) Soruşturma raporlarında karşılaşılan sorunlar, (6) Yaşanılan hukuki sorunların nedenleri, (7) Mevzuat kaynaklarına ulaşma yöntemi, (8) Disiplin soruşturmalarında yapılan hataların sonuçları, (9) Disiplin soruşturmaları konusunda yapılabilecek düzenlemeler, (10) Kararın yargıdan dönmemesi için sunulan öneriler, (11) Disiplin kurullarını oluşturmada dikkat edilecek hususlar, (12) Disiplin kurul özellikleri, disiplin kurullarında yaşanan sorunlar .

\subsection{Disiplin Amirinin (Yöneticilerin) Sahip Olması Gereken Özellikler}

Çalışmada ilk olarak iş yeri düzeninin sağlanmasında en önemli aktör olan disiplin amirlerinin (yöneticilerin) sahip olması gereken özelliklerin neler olduğu sorulmuştur. Katılımcılar 11 farklı ifadeyle bu özellikleri açıklamışlardır. Buna göre öncelikle disiplin amirlerinin disiplin hukuk bilgisi olan ve güncel mevzuatı takip eden ( $\%$ 21.5), personeline tarafsız davranan (\% 15.2), yönetim konusunda teknik bilgi ve deneyime sahip (\% 11.4), etik ve ahlaki değerlere sahip (\% 8.9), öncelikle uzlaşmacı ve iletişime önem veren ( $\%$ 8.9), disiplinli ve işini iyi yapan (\% 8.9), anlama ve muhakeme yeteneği olan (\% 7.6), konu odaklı nesnel yaklaşan (\%7.6), cesur (\%5.1), gerektiğinde teknik destek alan (\% 2.5), yasalara ve devletine bağlı (\% 2.5) kişiler olması gerektiği belirtilmiştir (Şekil 1). 



\subsection{Disiplin Amirlerinin Bilgi Eksiklikleri}

Disiplin amirlerinin bilgi eksiklikleri disiplin hukukunun uygulanmasında ve iş yeri düzeninin sağlanmasında önemli bir unsur oluşturduğu görülmüş ve katılımcılara disiplin amirlerinin ne tür bilgi eksiklikleri yaşadıkları sorulmuştur. Katılımcılar disiplin amirlerinin bilgi eksikliklerini 6 farklı ifadeyle açıklamışlardır. Buna göre disiplin amirlerinin büyük bir kısmının hukuk eğitimi almadığı, mevzuatı iyi bilmediği ve uygulayamadığı (\% 40) ifade edilmiştir. Bununla birlikte mevzuatın sürekli değiştiği ve amirlerin güncel gelişmeleri ve değişimleri takip etmede eksiklik yaşadığı (\% 20), disiplin hukuku ile ilgili olarak amirlerin usul konusunda bilgi eksiklikleri olduğu belirtilmiştir (\% 15). Disiplin amirlerinin deneyim eksikliği (\% 15), analitik düşünme ve doğru karar verememe (\% 7.5) ile gerektiği yerde hukuk biriminden destek almayı bilmeme (\% 2.5) de eksiklik olarak ifade edilmiştir (Şekil 2).

\section{Şekil 2. Disiplin Amirlerinin Bilgi Eksiklikleri}

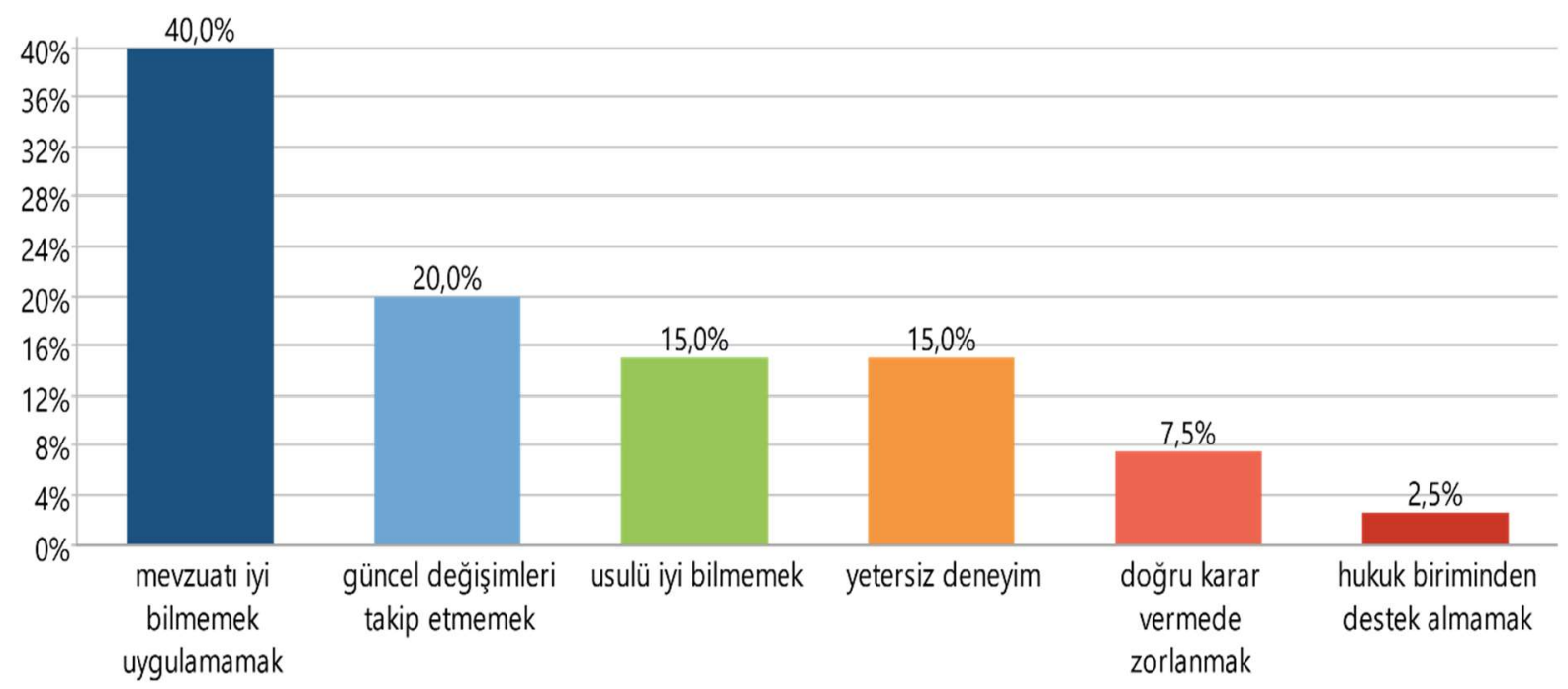




\subsection{Yükseköğretim Kurumlarında Karşılaşılan Disiplin Konuları}

Çalışmada katılımcılara yükseköğretim kurumlarında karşılaşılan başlıca disiplin konularının neler olduğu sorulmuş ve 12 farklı başlıkla ifade edildiği görülmüştür. Görevini gereği gibi yerine getirmeme (\% $\%$ 16.1) yükseköğretim kurumlarında karşılaşılan disiplin konularının başında gelmektedir. İşyeri düzenini bozma (\% 14.5), kişilerarası iletişimsizlik (\%12.9), amire itaatsizlik/saygısızlık (\% 11.3), mesai saatlerine uymama (\% 9.7), bireysel çıkar elde etme (\% 8.1), etik/ahlaki olmayan tutum (\% 6.5), mobbing (\% 6.5), kanunlara uygun davranmama (\% 4.8), yüz kızartıcı suçlar (\% 3.2), iftira (\% 3.2) ve işinde ilgisiz ve dikkatsiz davranma (\% 3.2) yükseköğretim kurumlarında karşılaşılan disiplin konularını oluşturmaktadır (Şekil 3).

\section{Şekil 3. Yükseköğretim Kurumlarında Karşılaşılan Disiplin Konuları}

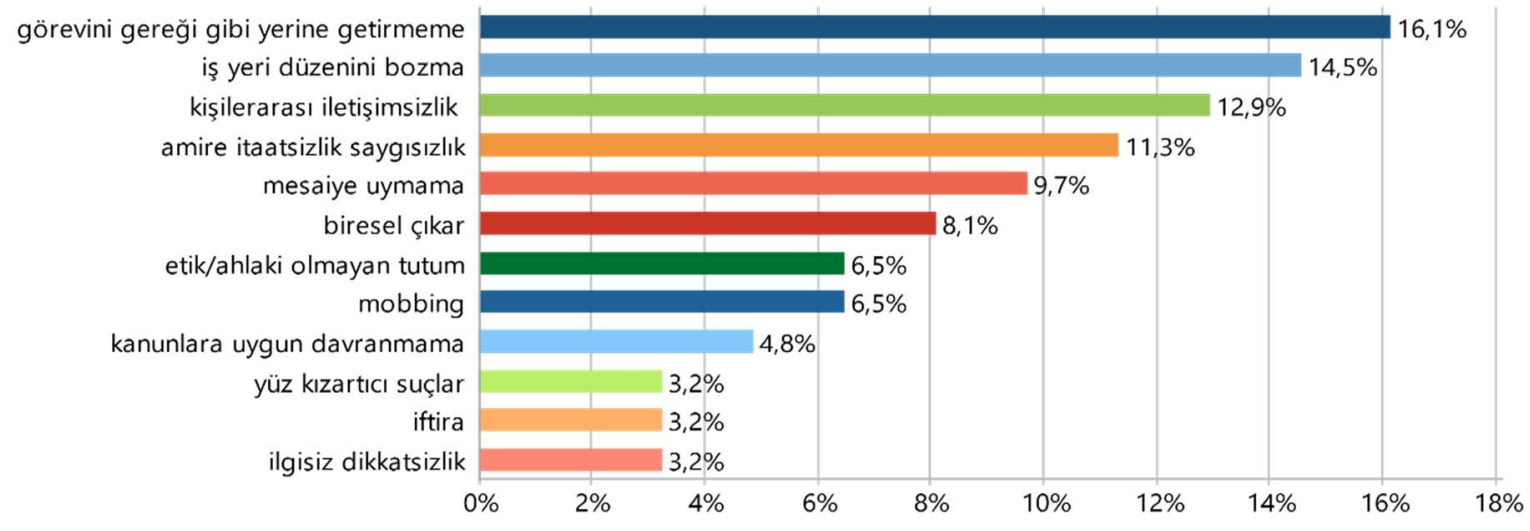

\subsection{Disiplin Amirlerinin Mevzuata Ulaşma Yöntemi}

Katılımcılara güncel mevzuata nasıl ulaştıkları sorulmuş ve 5 farklı yöntem kullanarak mevzuata ulaştıkları tespit edilmiştir. Katılımcılar büyük oranda mevzuata internet ortamından (\% 41.7) ulaşmaktadırlar. Bununla birlikte güncellenmiş rehber kitaplar kullanarak (\% 33.3), örnek kararları inceleyerek (\% 12.5), notlar tutarak (\% 8.3) ve gerektiğinde hukuk müşavirliğinden bilgi alarak ilgili mevzuata ulaşmaktadır (Şekil 4).

\section{Şekil 4. Mevzuata Ulaşma Yöntemi}
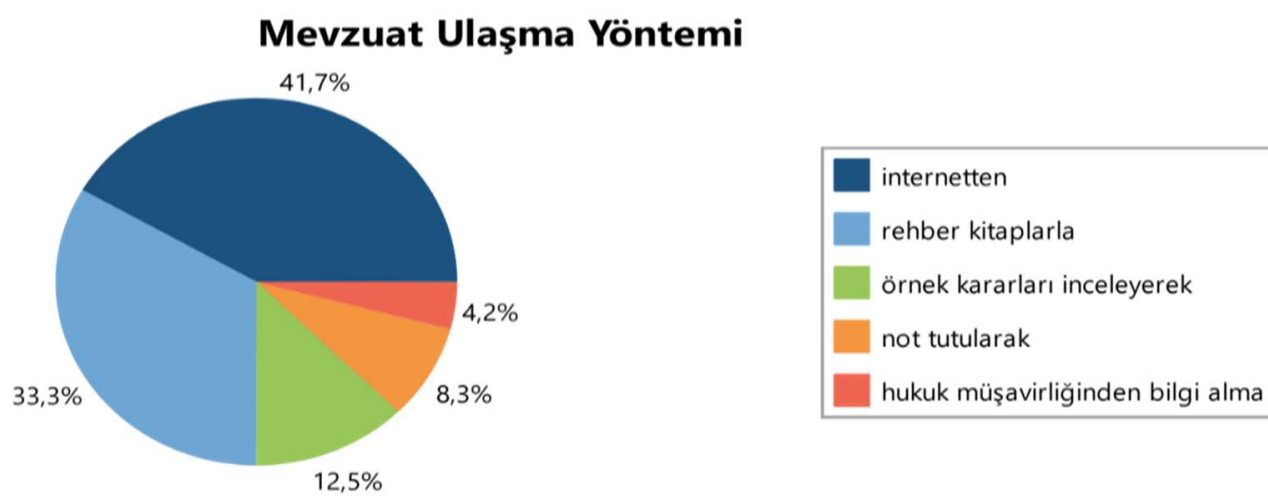


\subsection{Disiplin Soruşturmalarında Dikkat Edilmesi Gereken Hususlar}

Çalışmada katılımcılara disiplin soruşturmalarında nelere dikkat edilmesi gerektiği sorulmuş ve 17 farklı hususun öne çıktığı görülmüştür. Katılımcıların büyük bir kısmı disiplin soruşturmalarında soruşturmacıların tarafsızlığa ve dış etkilerden etkilenmemeye dikkat etmesi gerektiğini (10 katılımcı) vurgulamıştır. Bununla birlikte disiplin konusunu çok iyi anlamak (8), gizliliğe, etik ve ahlaki kurallara uymak (8), soruşturma safhalarına dikkat etmek (7), davet yazıları yazmak ve ifade alım süreçlerine uymak, tüm tanıkları dinlemek (4), konuyla ilgili ön çalışma yapmak (6) ve gereksiz soruşturmaları engellemek için uzlaşılabilecek durumda uzlaştırılarak gereksiz zaman kaybını önlemek (3), mevzuatı iyi incelemek (6) ve uygulamak (2), güncel gelişmelere bakmak (3) ve ihtiyaç duyulduğunda hukuki destek almak (6), iyi analiz edip eksiksiz raporlamak (4), konuya uygun ceza önerisi sunmak (2) dikkat edilecek hususlardır. Katılımcılar soruşturmacıların daha özenli davranmalarında adil soruşturma dağılımı yapılmasına dikkat edilmesi gerektiğini de belirtmişılerdir (Şekil 5).

\section{Şekil 5. Disiplin Soruşturmalarında Dikkat Edilmesi Gereken Hususlar}

\begin{tabular}{|c|c|c|c|c|c|c|c|c|c|c|c|c|c|c|c|}
\hline \multicolumn{16}{|l|}{ Kod Sistemi } \\
\hline \multicolumn{16}{|l|}{$\vee$ disiplin soruşturmalarinda dikkat edilmesi gereken hususlar } \\
\hline dış etkenleden etkilenmeme/tarafsız dinleme & - & & & & ๘ & $\square$ & & - &  & & & 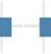 & & & 10 \\
\hline @ konuyu iyi anlamak & 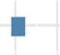 & & & & 1 & 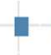 &  & & & 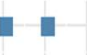 & & & & - & 8 \\
\hline soruşturma safhalarnna dikkat etme & & & $\square$ & & - & $\square$ & & & 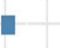 & & ष & & & $\square$ & 7 \\
\hline etik ahlaki vicdani sorumluluk & $\square$ & & 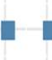 & 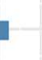 & & & & 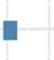 & & & - & 1 & & & 6 \\
\hline konuyla ilgili ön çalışma yapmak & & & &  & 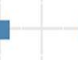 & $\square$ & &  & & $\square$ & 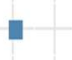 & & & & 6 \\
\hline hukuki destek alma & $\square$ & & 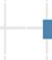 & 1 &  & & - & 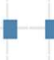 & 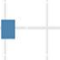 & & & & & & 6 \\
\hline konu ile ilgili mevzuatı/kararlan inceleme & & 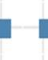 & 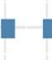 & & & & & & - & & & & & - & 6 \\
\hline os süreye dikkat etme & & & & 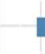 & 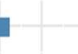 & & & &  & 【 & & 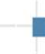 & $\mathbf{1}$ & - & 5 \\
\hline analiz ve eksiksiz raporlama & & & & & & & - & &  & - & & & & . & 4 \\
\hline güncel gelişmleri/mevzuatı takip etme & &  & & & & & & 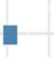 & & & & & & $\square$ & 3 \\
\hline öncelikle uzlaştırma yönelip gereksiz zaman kaybını önleme & & & 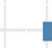 & 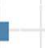 & & $\square$ & & & 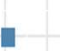 & & & & & & 7 \\
\hline tanıkları eksiksiz dinleme & & & & & & & & & 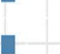 & $\pi$ & & & & & \\
\hline mevzuata uygun davranma & & & & & & & & & 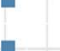 & & & & & & \\
\hline & & & & & & & & & 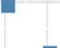 & & 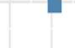 & & & & 2 \\
\hline konuya uygun ceza oner|s| & & & & & & & & & & 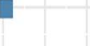 & & & & $\mathbf{a}$ & \\
\hline davet yzlarina/fifade alım süreçlerine dikkat etme & & & & & & & & & & & & 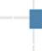 & & ! : & . \\
\hline egizilik & & & 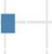 & & & & & & & & & 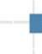 & & & 2 \\
\hline adil soruşturma dağılımı & 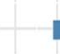 & 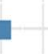 & & & & & & & & & & & & & \\
\hline$\sum$ TOPLAM & & & & & 53 & 5 & 3 & 5 & & 35 & 14 & 45 & & 487 & 7 \\
\hline
\end{tabular}

\subsection{Disiplin Soruşturma Raporlarında Karşılaşılan Sorunlar}

Katılımcılara disiplin soruşturma raporlarında ne tür hata ve eksikliklerle karşılaşıldığı sorulmuş ve 11 farklı kategoride sorunlar tespit edilmiştir. Soruşturma raporlarında çoğunlukla tanıkları 
dinlememe gibi eksik soruşturmaya dayalı sorunlar yaşanmaktadır ( $\%$ 17.2). Bununla birlikte özensiz raporlama (\% 12.5), muhakeme edememe, kanaat belirtmeme ya da illiyet bağı kuramama gibi kararı sonuçlandırmaya yönelik sorunlar (\% 12.5), soruşturmayı deneyimsiz soruşturmacılarla ve teknik destek almadan yürütme (\% 9.4), somut delilsiz ya da taraflı karar verme (\% 9.4), süreye dikkat etmeme (\% 9.4), güncel mevzuatı kullanmama (\% 7.8), yanlış mevzuatı kullanma (\% 6.3), soruşturma dizgesine uymama (\% 6.3), savunma hakkına uymama (\% 4.7) ve soruşturmacının unvan denkliği ya da üstünlüğü, tanıklara yemin ettirmeme ya da şüpheliye yemin ettirme, davet yazılarını uygun yazmama gibi usûl hataları ile karşılaşılmaktadır (Şekil 6).

\section{Şekil 6. Soruşturma Raporlarında Karşılaşılan Sorunlar}

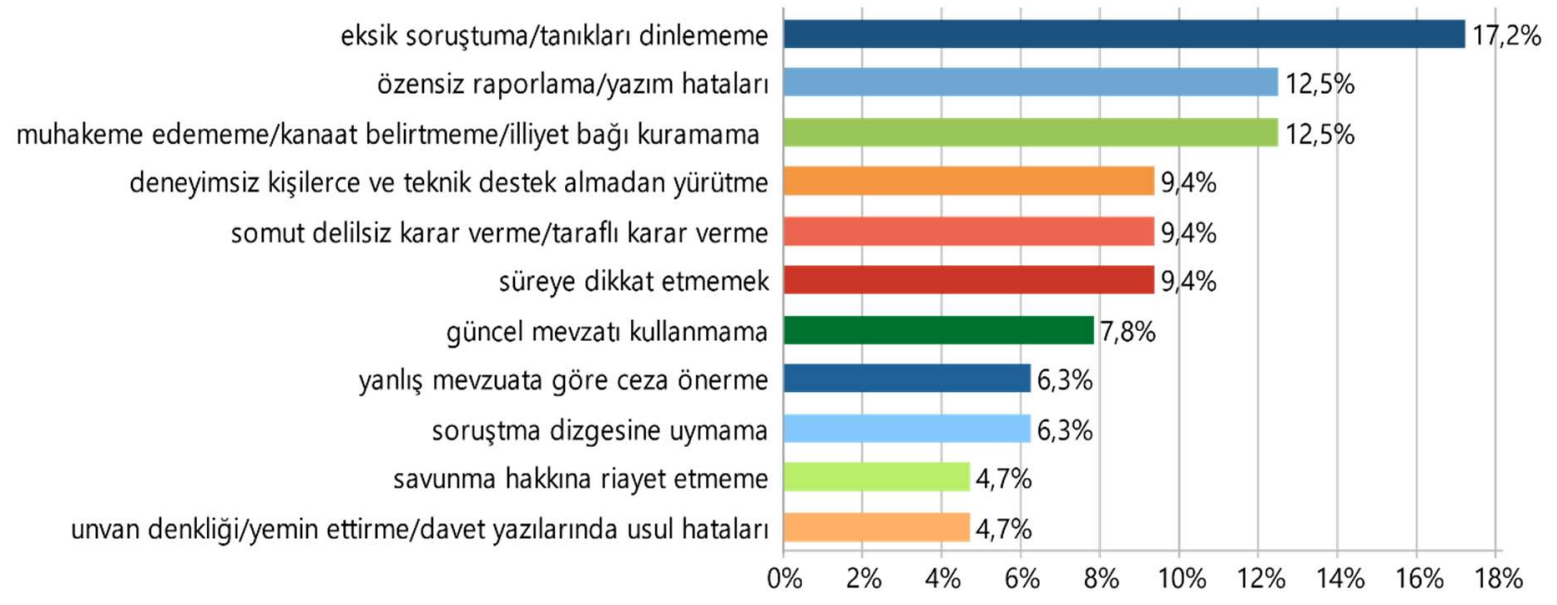

\subsection{Disiplin Soruşturmalarında Yaşanan Hukuki Sorunların Nedenleri}

Katılımcılara disiplin soruşturmalarında yaşanan hukuki sorunların nedenleri sorulmuş ve usûlden kaynaklı, kişilerden kaynaklı ve mevzuatın değişmesinden kaynaklı olarak 3 farklı kategoride ifade edildiği görülmüştür. Katılımcılar yaşanan hukuki sorunların büyük oranda usul hatalarından (\% 54) ve kişilerden (\% 43) kaynaklandığını ifade etmişlerdir. Bununla birlikte mevzuatın sık sık değişmesinin hukuki sorunlar ortaya çıkardığı belirtilmiştir (Şekil 7).

\section{Şekil 7. Disiplin Soruşturmalarında Yaşanan Hukuki Sorunların Nedenleri 1}




Katılımcılar usûlden kaynaklı sorunların; soruşturma safhalarına uymama, süreye dikkat etmeme, güncel mevzuatı uygulamama veya yanlış mevzuatı uygulama, eksik inceleme, illiyet bağı kuramama ve konuya uygun ceza vermeme gibi hata ve eksiklikler olarak belirtmişlerdir. Kişilerden kaynaklı sorunlar ise; dikkatsiz ve özensiz davranma, tarafsız ve adil olamama, etkilenerek karar verme, mevzuatı bilmeme, net karar verememe ve gizliliğe, etik kurallara uymama gibi hata ve eksikliklerden kaynaklanmaktadır (Şekil 8).

\section{Şekil 8. Disiplin Soruşturmalarında Yaşanan Hukuki Sorunların Nedenleri 2}

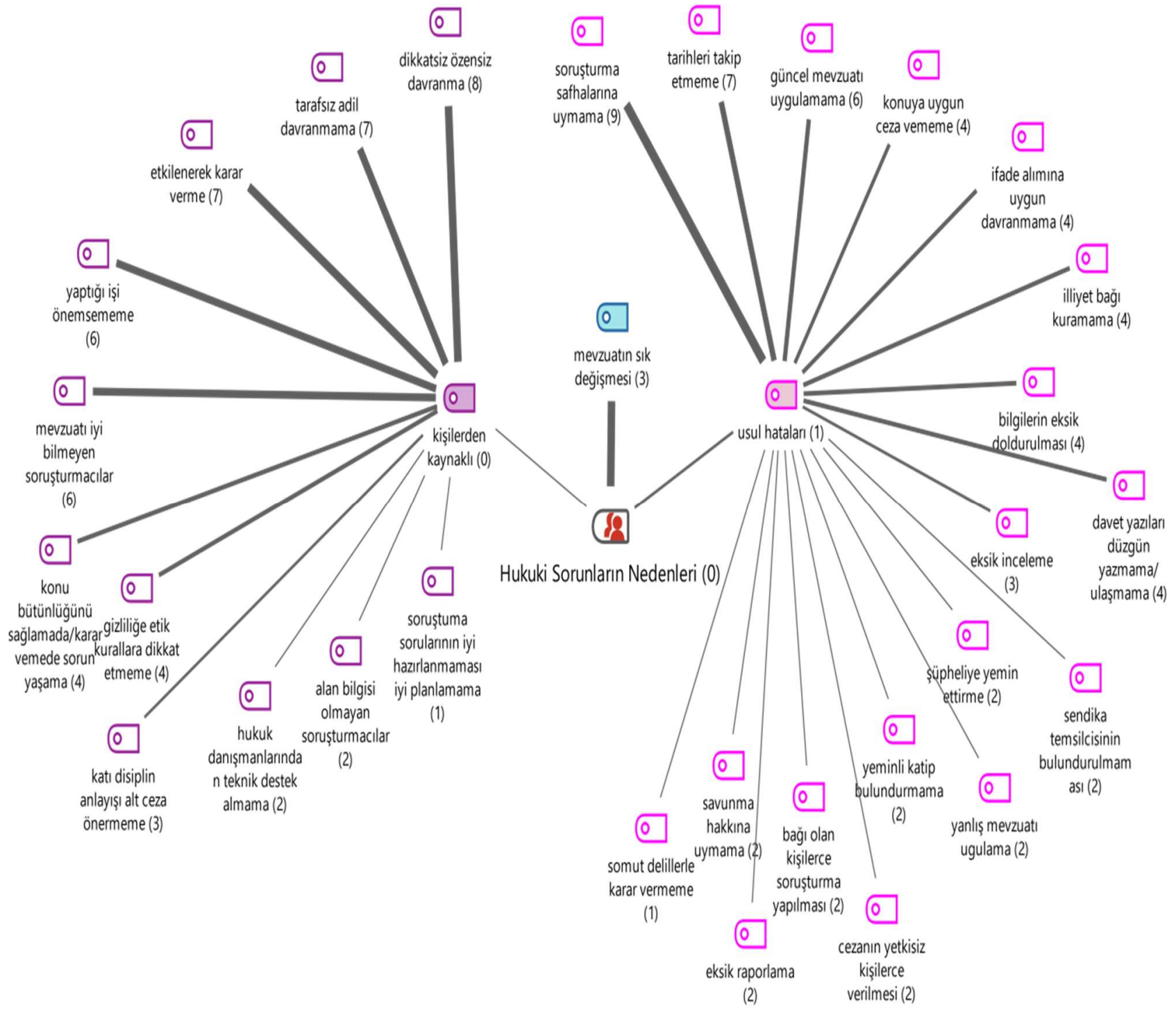

\subsection{Disiplin Kurulu Üyelerinin Sahip Olması Gereken Özellikler}

Katılımcılara disiplin kurulu üyelerin sahip olması gereken özellikler neler olmalıdır diye sorulmuş ve 9 farklı özellikle açıklandığı görülmüştür. Disiplin kurul üyelerinin öncelikle disiplin hukuku bilgisine ve deneyimine sahip (\% 25.9) olması önemli görülmüştür. Aynı zamanda kurul üyelerinin; etik ahlaki nitelikler (\% 14.8), cesur ve dik duruşlu (\% 14.8), uyumlu (\% 11.1) gibi olumlu kişilik 
özelliklerine sahip olması öne çıkmaktadır. Bununla birlikte teknik özellikler olarak; hukuk müşavirliği ile irtibatlı (\% 11.1), güncel gelişmeleri takip eden (\% 7.4), raportörlük bilgisine sahip (\% 7.4) olması gerekli özellikler arasında yer almıştır. Kurul üyelerinin disiplin cezası almamış olması (\% 3.7) ve akademik titreye dikkat edilmesi (\% $\%$ 3.7) de gereken özellikler arasında sıralanmıştır (Şekil 9).

Şekil 9. Disiplin Kurulu Üyelerinin Sahip Olması Gereken Özellikler

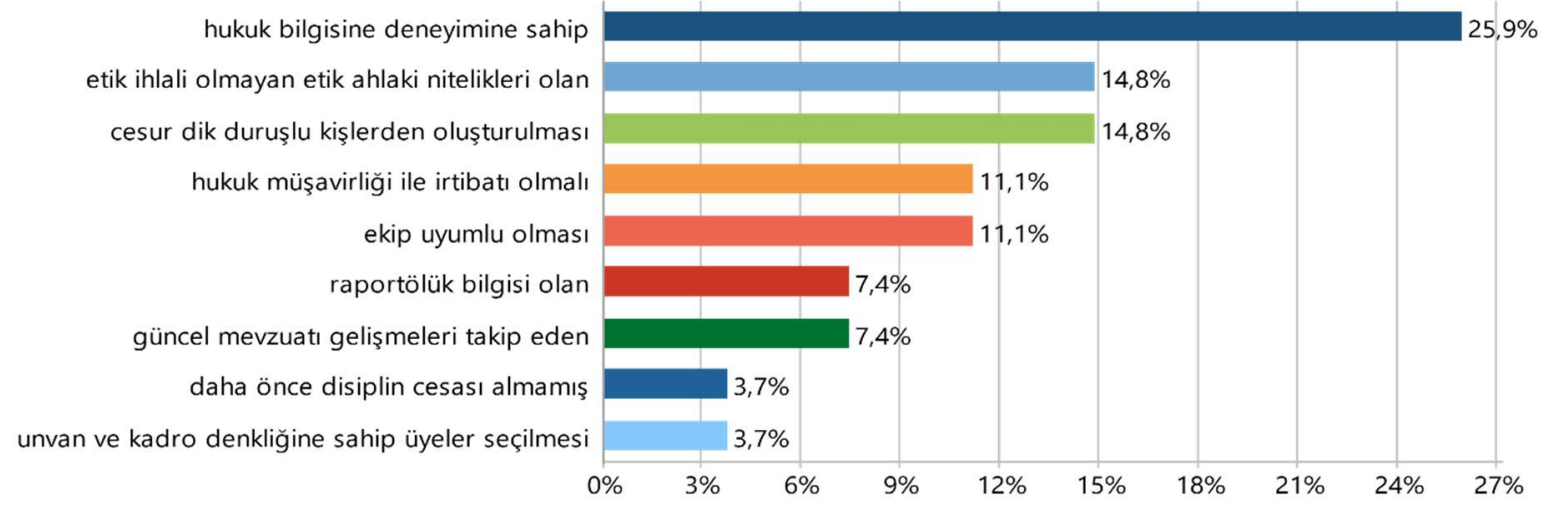

\subsection{Disiplin Kurullarını Oluşturmada Dikkat Edilecek Hususlar}

Çalışmada katılımcılar, disiplin kurullarını oluşturmada dikkat edilmesi gereken hususları 10 farklı kategoride açıklamışlardır. Katılımcılara göre öncelikle disiplin kurulları oluşturulurken üyelerin soruşturmanın konusuna uygun uzman kişilerden oluşturulmasına ( $\%$ 22) dikkat edilmesi gerekmektedir. Kurul üyelerinin kimseden etkilenmeyen (\% 16), tarafsız (\% 12), unvan denkliğine sahip (\% 10), ahlakl1/vicdanl1/informal grup veya kişilerle bağı olmayanlardan (\% 10) belirlenmesi önemli görülmüş̧tür. Aynı zamanda katılımcılara göre; sorumluluk sahibi, liyakatli, iyi iletişim kurabilen kişilerden seçilmesi, kanunda belirtilen maddelere uygunluğu, iş yükü, disiplin cezası olmaması kurulları oluşturmada dikkate alınmalıdır (Şekil 10).

\section{Şekil 10. Disiplin Kurullarını Oluşturmada Dikkat Edilecek Hususlar}






\subsection{Disiplin Kurullarında Yaşanan Sorunlar}

Katılımcılar disiplin kurullarında yaşanan sorunları 12 farklı kategoride ele almışlardır. Disiplin kurullarında dosyanın tüm üyelerce çok iyi anlaşılamaması (\% 20.9) en önemli sorun olarak görülmüştür. Bununla birlikte raportörün sunumunun yetersizliği (\% 14.9), güncel mevzuatın uygulanmaması (\% 11.9), her fikrin açıklanmaması (\% 11.9), tarafsız olunamaması (\% 10.4), kadro denkliğine dikkat edilmemesi (\% 7.5) gibi sorunlar belirtilmiştir (Şekil 11).

\section{Şekil 11. Disiplin Kurullarında Yaşanan Sorunlar}

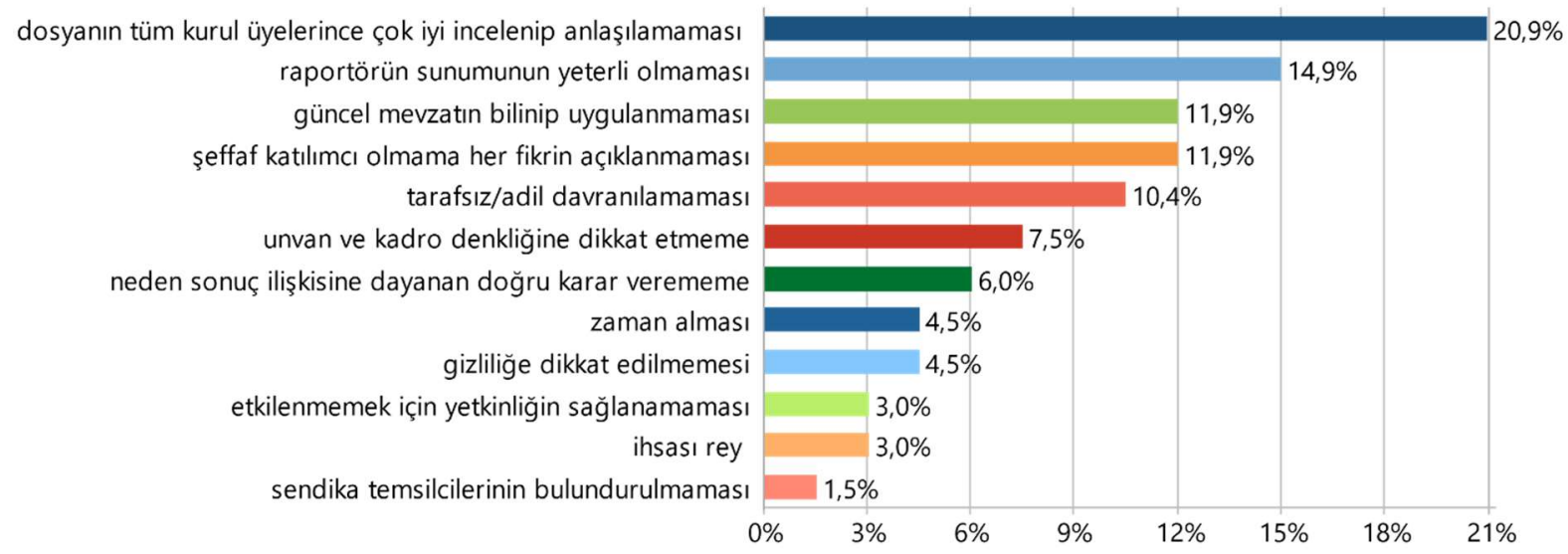

\subsection{Disiplin Kurullarında Yapılan Hataların Sonuçları}

Çalışmada katılımcılara disiplin kurullarında yapılan hataların ne tür sonuçlar ortaya çıkardığg sorulmuş, 8 farklı sonuç ortaya çıkardığı belirtilmiştir. Buna göre katılımcılar öncelikle yapılan hataların maddi zararlara (10 katılımcı) yol açtığını belirtmiştir. Aynı zamanda kurumsal itibarın zarar görmesine (9), zaman kaybı ve yargının yükünün artmasına (9), soruşturmacılar ve kişilerde mağduriyete (7), suçluların ceza almamalarına (6), işlemin iptaline (4), zaman aşımına uğramasına (2) ve motivasyon kaybına (2) yol açtı̆̆ı da belirtilmiştir (Şekil 12).

\section{Şekil 12. Disiplin Kurullarında Yapılan Hataların Sonuçları}

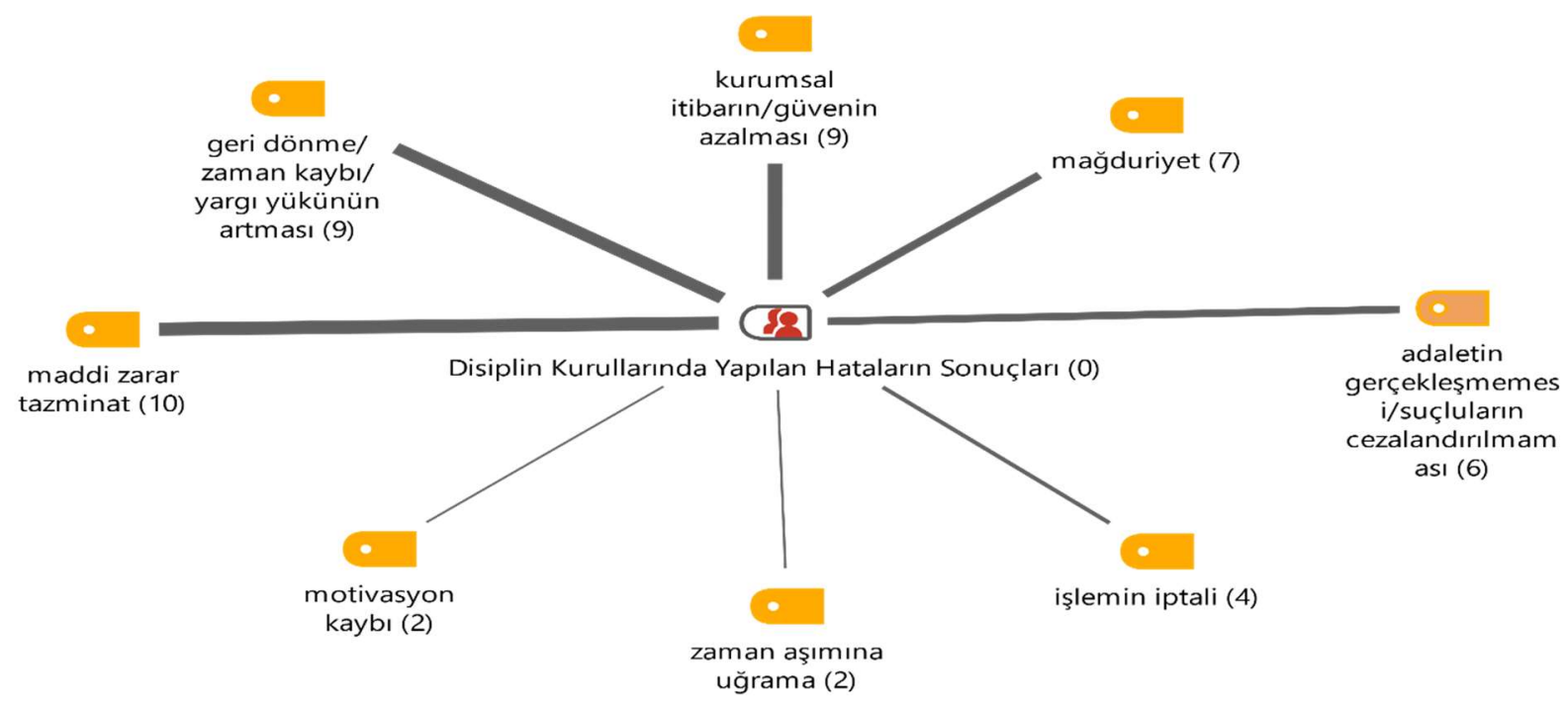




\subsection{Disiplin Hukukunun Adaletli İşlemesi İçin Yapılabilecek Düzenlemeler}

Katılımcılara disiplin hukukunun adaletli işlemesi için ne tür düzenlemeler yapılabileceği sorulmuş ve 15 farklı öneri sunulduğu görülmüştür. Buna göre; öncelikle soruşturmacılara ve disiplin amirlerine disiplin hukukuyla ilgili düzenli eğitim uygulanması gerektiği ve disiplin soruşturmacıları ve kurullarının yıpratılması için düzenlemeler yapılması (\% 15.3) gerektiği belirtilmiştir. Bu konuda gönüllülük sağlanmasına (\% 11.1), koordinasyon ve destek sağlayacak etkili bir birimin oluşturulmasına (\% 11.1), disiplin hukuk bilgisi (\% 8.3) ve deneyimi olan (\% 8.3) kişilerin seçilmesine yönelik düzenlemeler de önemli görülmüştür. Katılımcılar disiplin hukuku bilgisi konusunda sıkıntılar yaşandığını belirterek ayrıca, soruşturmaların hukuk birimlerince yürütülmesi (\% 5.6), önce hukuk biriminin çok iyi incelemesi (\% 5.6), geniş kapsamlı hukuk ofisi oluşturularak yükün azaltılması (\%4.2), barodan gönüllü avukatların desteğinin sağlanması (\% 1.4) ve iş yükünü azaltacak sekretarya sağlama (\% 1.4$)$ yönünde düzenlemelerin yapılabileceğini vurgulamıştır. Soruşturmaların işi bilen olmaları nedeniyle genellikle aynı kişiler üzerinden yürütüldüğü ya da iş yükünün dikkate alınmadığı, tarafsızlığı sağlamak için farklı bölümlerden soruşturmacıların görevlendirilmesinin iyi olacağı (\%2.8) konusunda görüş belirterek bu hususları dikkate alacak düzenlemelerin yapılabileceğini de ifade ettikleri görülmüştür. Yine mevzuattaki belirsizlerin giderilmesi ve soruşturmacılara rehber olacak kitaplar sağlanması da öneriler arasında sıralanmıştır (Şekil 13).

Şekil 13. Disiplin Hukukunun Adaletli İşlemesinde Yapılabilecek Düzenlemeler






\subsection{Verilen Kararların Yargıdan Dönmemesi İçin Öneriler}

Yapılan araştırma sonucunda verilen kararların önemli ölçüde idari mahkemelerden döndüğü görülmüş ve katılımcılara bu yönde neler yapılabileceği sorulmuştur. Katılımcılar öncelikle disiplin soruşturmalarında mevzuatı bilen soruşturmacıların görevlendirilmesinin (\%18), hukuk ofisince sistemli bir koordinasyon ve destek sağlanmasının (\% 16.4) ve soruşturmanın mevzuata uygunluğunun çok iyi incelenmesinin (\% 14.8) yargıdan dönmemesinde etkili olacağını belirtmiştir. Yine eğitimlerle bilgi eksikliklerinin giderilmesi, raportörün ve soruşturmacıların özenli seçilmesi, kanaatin net verilmesi, tarafsızlığa ve kimsenin etkisinde kalınmadan karar verilmesi, süre takibinin çok iyi yapılması da kararların yargıdan dönmemesi için önemli hususlar olarak belirtilmiştir (Şekil 14).

Şekil 14. Soruşturma Kararlarının Yargıdan Dönmemesi İçin Yapılan Öneriler

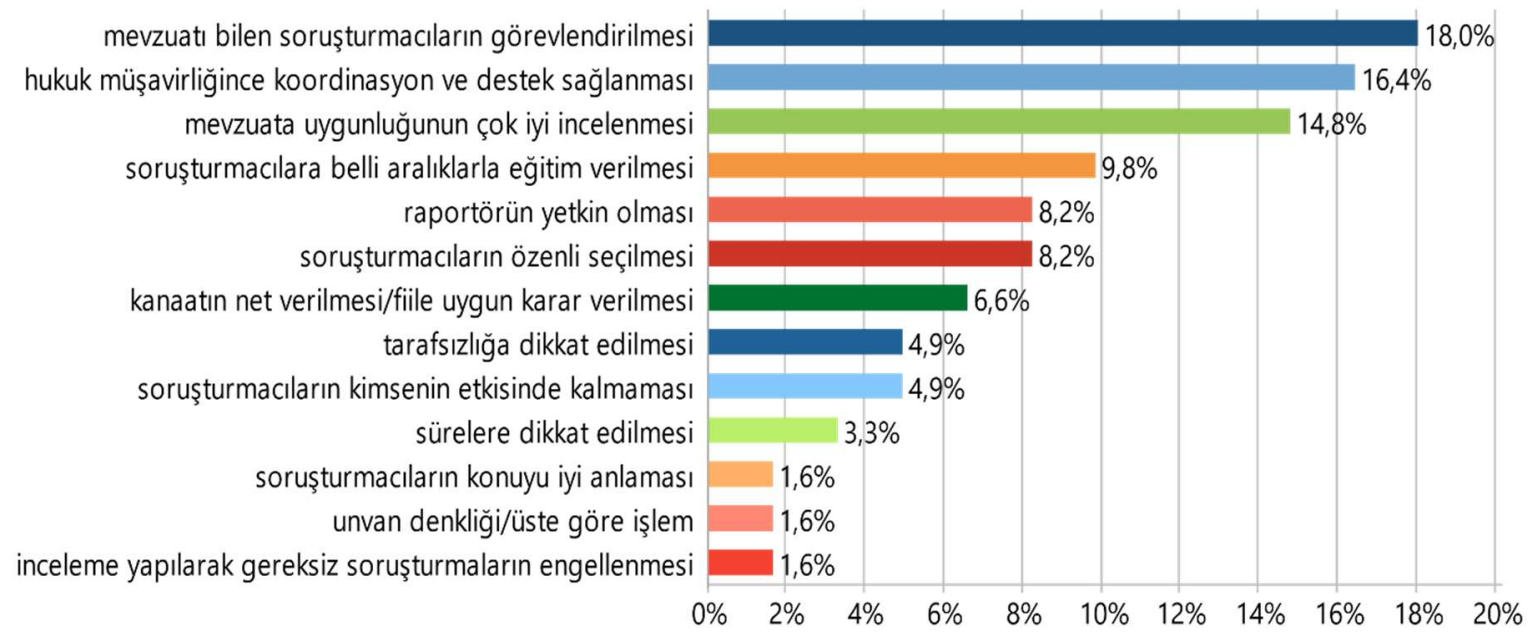

\subsection{Bulguların Tartışılması ve Sorunlara Yönelik Çözüm Önerileri}

Çalışmadan elde edilen bulgulara göre, disiplin amir ve disiplin kurul üyelerinin disiplin hukuk bilgisi öne çıkan kavram olmuştur. Yükseköğretim kurumlarında disiplin amirlerinin büyük bir çoğunluğu alanlarında uzman olmalarına rağmen herhangi bir disiplin hukuku eğitimi almamışlardır. $\mathrm{Bu}$ yönde sorunlarla karşılaşmakta bu sorunları zamanla kazandıkları deneyimle, kişisel olarak kendilerini geliştirerek, hukuk biriminden destek alarak aşmaya çalışmaktadırlar. Aynı zamanda disiplin soruşturmaları disiplin hukuku bilgisini gerektirmekle birlikte, mevzuatın sürekli değişmesi, güncel değişimleri takip etmeyi zorunlu kılmaktadır. Soruşturma sonucunda verilen kararların bozulma gerekçelerinde usûl hatalarının öne çıkması yine disiplin hukuku bilgisinin yetersiz olmasının etkili olabileceğini göstermektedir. Elde edilen bulgular yapılan çalışmalarda ve Danıştay kararlarında da öne çıkan konularla benzerlik göstermektedir. Genel olarak değerlendirildiğinde ise disiplin amirlerinin yaşadığı sorunlar şu şekilde özetlenebilir:

(1) Disiplin hukuku mevzuatı sık değişmektedir. 
(2) Yöneticiler çoğunlukla disiplin hukukunu deneme-yanılma ile öğrenmektedir.

(3) Disiplin amirleri disiplin hukuku konusunda eğitilmiş-nitelikli soruşturmacı bulamamaktadır.

(4) Soruşturma raporlarında çoğunlukla usul hataları ile karşılaşılmaktadır. Usul ile ilgili mevzuatın bilinmemesi hataların en önemli sebebidir.

(5) Soruşturmacılar tarafından isnat edilen eylemle şüpheli arasında illiyet bağı kurulamamaktadır.

(6) Soruşturma konusunda gerekçe ortaya konulmasından ceza teklif edilmesi,

(7) Soruşturma işlemi konusuyla teklif edilen hukuki sonuç arasında bir bağ kurulamaması,

(8) Zaman aşımı sürecinin gözden kaçırılması,

(9) Yöneticilerin disiplin hukuku konusunda olan eğitimi almamış olmamaları,

(10) Disiplin hukuku alanında kaynak ve örnek yetersizliği,

(11) Eksik incelemeye dayalı disiplin soruşturması raporu hazırlanması

(12) Disiplin amirlerinin disiplin cezası vermede karşılaştıkları sorunlardır.

\section{Çözüm önerileri;}

(1) Disiplin hukuku mevzuatı üniversite düzeyinde oluşturulacak rektöre doğrudan bağlı Soruşturma Değerlendirme Komisyonu (SDK) tarafından izlenerek ilgili birimlere bilgilendirme yapmas1,

(2) Üniversite bünyesindeki birimlerde görev yapan idari ve akademik yöneticiler disiplin hukuku konusunda SDK üyelerince hizmetiçi eğitime alınması,

(3) Üniversite genelinde soruşturmacı olarak görevlendirilebilecek soruşturmacıların SDK tarafından eğitimden geçirilmesi,

(4) Soruşturma raporlarında sıkça görülen usûl hatalarının olmaması için soruşturma raporları tamamlandiktan sonra SDK'ya teslim edilerek incelenmesi ve bu incelemeden sonra uygulamaya geçilmesi,

(5) Şüpheliler hakkında isnat edilen fiille fail arasında suçun yapısal unsurları bakımından illiyet bağı kurulması kontrolü yine SDK tarafından yapılması,

(6) Soruşturmalarda neden ve sonuç ilişkisi ortaya konulurken gerekçenin yazılıp yazılmadığının yine raporda SDK tarafından gerekli kontrolün yapılması,

(7) Soruşturma konusuyla varılan sonuç arasında işlenen fiilin kanuni tarifindeki unsurların gerçekleşme durumunun yazılıp yazılmadığının yine kontrolünün SDK tarafından yapılması,

(8) Soruşturma sürecinde aşımına uğranılmaması açısından hukuk müşavirliğince yaptırılacak bir yazılım programına göre soruşturmaların takip edilmesi ve soruşturmacılara gerekli uyarıların yapılmas1,

(9) Yöneticilerin disiplin hukuku konusunda eğitim almalarının sağlanması için üniversitelerde uzaktan eğitim kanallarının kullanılması, 
(10) Disiplin hukuku ve soruşturmalar konusunda SDK tarafindan hazırlanacak bültenle meri mevzuat ve örnek rapor ile dosyalar paylaşılmadır.

(11) Eksik incelemeye dayalı disiplin soruşturması raporu hazırlanması durumunda SDK rehber ve destek olmalıdır.

(12) Disiplin amirleri disiplin cezası vermede SDK'nın görüşünü almalıdır.

Disiplin kurullarında yaşanan sorunlar şu şekilde özetlenebilir:

(1) Dosya hakkında kurul üyelerinin bilgisinin olmaması,

(2) Raportörlük görevinin tam anlaşılmaması,

(3) Kurul kararının niteliğinin farklı algılanması,

(4) Kurul üyelerinin görüşlerinin bildirmede çekingen davranmaları,

(5) Soruşturma dosyalarının görevli olmayan kurullarda görüşülmesi,

(6) Kurullarda karar ve itiraz kavramlarının birbirine karıştırılması,

(7) FETÖ dosyaları gibi özel durumların diğer disiplin işlemleriyle birbirine karıştırması,

(8) Kurul toplantılarına sendika temsilcisinin çağrılmaması,

(9) Kurul üyelerinin disiplin hukuku alanında eğitim almamış olmaları,

(10) Kurul üyelerinin sık değişmesi bu sorunlar arasında gösterilebilir.

Disiplin kurullarında yaşanan sorunların çözümüne yönelik sunulacak öneriler şu şekilde siralanabilir:

(1) Disiplin kurullarında görüşülen dosyalar raportörler tarafından bir A4 kağıdına özetlenerek kurul üyelerine önceden dağıtılmalıdır.

(2) Kurullarda raportörlük görevini üstlenecek üyeler görev ve sorumluluklar açısından SDK tarafından hizmetiçi eğitime tabi tutulmalıdır.

(3) Kurullarda verilen kararlar SDK'nın değerlendirmesinden sonra uygulamaya geçmelidir.

(4) Her kurul üyesinin dosyanın görüşülmesi sırasında görüşlerini beyan etme zorunluluğu olmalidir.

(5) Soruşturma dosyaları kurullara girmeden önce doğru kurulun yetki alanını girip girmediği SDK tarafindan kontrol edilmelidir.

(6) Özellikle üniversite disiplin kurulunda SDK'nın bir üyesinin bulunması, hukuka uygun kararların alınması ve kurula yapılmış itirazların doğru değerlendirilmesi açısından önemlidir.

(7) FETÖ soruşturmaları normal bir soruşturma gibi değerlendirilmeyip düzenlenmiş ayrı bir uygulama olduğu ortaya konulmalıdır.

(8) Kurul toplantılarına şüphelinin üyesi olduğu sendika temsilcisinin çağrılması önemlidir. Çünkü, sendikalar özlük haklarının savunulmasında önemli role sahiptirler. 
(9) Kurul üyeleri disiplin ve ceza hukuku konusunda SDK tarafından hizmetiçi eğitime tabi tutulmalıdir.

(10) Kurul üyeleri adaleti sağlamanın devamlılı̆̆ açısından zorunlu haller dışında sık değiştirilmemelidir.

\section{SONUÇ}

Disiplin kurallarının amacı özelde iş yeri düzenini genelde toplumsal düzeni (kamu düzeni) sağlamaktır. Dolayısıyla disiplin soruşturmalarının temel işlevi özelde iş yerinde, genelde toplumsal yaşam bakımından hayati önem taşıyan kuralların ihlalini disiplin suçu olarak tanımlamak ve bunlar karşılı̆̆ında idari yaptırımlar ortaya koymaktır.

Disiplin soruşturmaları başta işyerinde adaletin gerçekleştirilmesi ve iş yeri düzeninin devamlılı̆̆ açısından haksızlıkları engellemek anlamında çok önemlidir. Dolayısıyla disiplin soruşturmalarının hukuk düzeni içerisinde ve hukuka uygun gerçekleştirilmesi gerekmektedir.

Disiplin soruşturmalarının hukuka uygun olmasında en önemli pay disiplin amirleri, disiplin soruşturmacıları ve disiplin kurullarınındır. Ancak, disiplin amirlerinin, disiplin soruşturmacılarının ve disiplin kurulları üyelerinin disiplin hukuku konusunda eğitim almamış olmaları ve yeterli bilgi ve deneyime sahip olmamaları önemli bir sorun olarak ortaya çıkmaktadır. Bu sorunun çözümünde bu görevleri yerine getiren kamu görevlilerine uzman kişilerce uygun zaman ve ortamlarda gerçekleştirilecek hizmetiçi eğitimler önemli bir paya sahip olacaktır. Bunun yanı sıra özellikle üniversitelerde rektöre doğrudan bağlı ve danışma-koordinasyon-kontrol görevleri olan bir Soruşturma Değerlendirme Komisyonu (SDK) oluşturulması soruşturma dosyalarındaki usûl hatalarını en aza indirme, eksikleri tamamlattırma ve uygulama birliği açısından önemli bir işlev üstlenecektir. 


\section{KAYNAKÇA}

Akyılmaz, B. (2000). Anayasal Esaslar Çerçevesinde Kamu Personeli Disiplin Hukuku ve Uygulamadaki Sorunlar. Ankara Hacı Bayram Veli Üniversitesi Hukuk Fakültesi Dergisi, $6(2)$.

Arpacıoğlu, İ. T. (2015). Yükseköğretim Kurumları Yönetici, Öğretim Elemanı ve Memurları Disiplin Yönetmeliğindeki Değişiklikler Hakkında Bir Değerlendirme. Trakya Üniversitesi Sosyal Bilimler Dergisi, 17(2), 235-242.

Ayturan, B. (2018). Yükseköğretim Personelinin Göreve İlişkin Suçlarının Soruşturması. Türkiye Adalet Akademisi Dergisi, (35), 429-467.

Bucaktepe, A. (2015). Disiplin Makamlarının Disiplin Cezası Verme Yetkileri Üzerine Bir Değerlendirme. Ankara Hacı Bayram Veli Üniversitesi Hukuk Fakültesi Dergisi, 19(2), 199224.

Çınarlı, S. (2011). Yükseköğretim Kurumlarında Disiplin Soruşturması Sorunu ve Alman Disiplin Mahkemeleri Modeli Önerisi. Selçuk Üniversitesi Hukuk Fakültesi Dergisi, 19(1), 39-63.

Demircioğlu, M. Y. (2014). Üniversitelerde 2014 Y1lından Önce İşlenen İntihal Suçlarıyla İlgili Disiplin Soruşturması ve Cezalandırma Sistemi. Ankara Barosu Dergisi, (4).

Duman, B. (2012). Yükseköğretim Ceza ve Disiplin Soruşturması, Seçkin Yayıncılık: Ankara.

Ercan, M. S. (2019). Yükseköğretim Personeli Disiplin Hukukuna Uygulanacak Usule İlişkin Değerlendirme. Yeditepe Üniversitesi Hukuk Fakültesi Dergisi, 55-71.

Erdoğan, A. (2019). 2547 sayıl yükseköğretim kanunu çerçevesinde yükseköğretim kurumlarında akademik ve idari personele uygulanan disiplin soruşturmasının hukuki niteliği ve usulü, Yayımlanmamış Yüksek Lisans Tezi. Süleyman Demirel Üniversitesi, Sosyal Bilimler Enstitüsü, Kamu Yönetimi Ana Bilim Dalı.

Erkul, H.; Kanten, P. ve Aydın, D. (2019). Örneklerle Yükseköğretim Kurumlarında Disiplin ve Ceza Soruşturmaları, ÇOMÜ Yayınları: Çanakkale.

Günday, M. (2011). İdare Hukuku, 10. Bask1, Ankara.

Gürgen, L. (2018). 2547 Sayılı Yükseköğretim Kanunu'nda Görevi Kötüye Kullanma Suçunun Soruşturma Usulü. Uyuşmazlık Mahkemesi Dergisi, (11), 145-168.

Mesci, H. ve Aydın, V. (2017). Yükseköğretim Kurumlarında Çalışan Kamu Görevlilerinin Ceza Soruşturma Usûlü. Süleyman Demirel Üniversitesi Hukuk Fakültesi Dergisi 7(2), 1-91. 
Seçtim, H. ve Erkul, H. (2020). Yükseköğretim Kurumlarında Görev Yapan Akademik Personelin Ceza Soruşturmaları Üzerine Nitel Bir Araştırma. Management and Political Sciences Review, 2(2), 34-68.

Turhan, M. K. (2019). Yükseköğretim Personeli Disiplin Soruşturma Usulüne İlişkin Olarak 2547 Sayılı Yükseköğretim Kanunu’nda Yapılan Değişikliklerin Değerlendirilmesi. Legal Hukuk Dergisi, 17(201), 3825-3864.

Yılmaz, D. (2013). Yükseköğretim Personeli Ceza Soruşturması, Yasal Eksiklikler ve Çözüm Önerileri, Erzincan Üniversitesi Hukuk Fakültesi Dergisi, 17(1)-2.

Danıştay Kararları (2021). http://emsal.danistay.uyap.gov.tr erişim tarihi: 03.04.2021

Disiplin/ sozluk.gov.tr. erişim tarihi: 13.05.2021

657 sayılı Devlet Memurları Kanunu, https://www.mevzuat.gov.tr/ erişim tarihi: 21.04.2021

1609 sayılı Kanun ibaresi; https://www.resmigazete.gov.tr/ erişim tarihi: 21.04.2021

2547 sayılı Yükseköğretim Kanunu, https://www.mevzuat.gov.tr/ erişim tarihi: 21.04.2021

2577 sayılı İdari Yargilama Usul Kanunu, https://www.mevzuat.gov.tr/ erişim tarihi: 21.04.2021

2709 sayılı T.C. Anayasası, https://www.mevzuat.gov.tr/ erişim tarihi: 03.04.2021

2914 sayılı Yükseköğretim Personel Kanunu. https://www.mevzuat.gov.tr/ erişim tarihi: 21.04.2021

3628 sayılı Mal Bildiriminde Bulunulması, Rüşvet ve Yolsuzluklarla Mücadele Kanunu.

https://www.mevzuat.gov.tr/ erişim tarihi: 21.04.2021

4483 sayılı Memurlar ve Diğer Kamu Görevlilerinin Yargılanması Hakkında Kanun, https://www.mevzuat.gov.tr/ erişim tarihi: 21.04.2021

4857 sayılı İş Kanunu. https://www.mevzuat.gov.tr/ erişim tarihi: 21.04.2021

5237 sayılı Türk Ceza Kanunu, https://www.mevzuat.gov.tr/ erişim tarihi: 21.04 .2021

6764 sayılı Kanunla 2547 sayılı Yükseköğretim Kanunu'nun 53. maddesine yapılan değişiklikler ve eklemeler, https://www.resmigazete.gov.tr erişim tarihi: 21.04.2021

7243 sayılı Yükseköğretim Kanunu ile Bazı Kanunlarda Değişiklik Yapılmasına Dair Kanun, https://www.resmigazete.gov.tr erişim tarihi: 21.04.2021 


\section{EXTENDED SUMMARY}

Discipline is expressed as the whole of the measures taken to ensure that people comply with the laws and rules regulating public services, and the thoughts and behaviors of the general public. In the presence of a violation, the administration applies disciplinary penalties according to administrative procedures.

The organization and functioning of higher education institutions are regulated by the Higher Education Law No. 2547. Article 53 of this Law determines the general principles regarding disciplinary and criminal matters. Public officials working in higher education institutions are divided into administrative personnel and academic personnel. In terms of disciplinary law, academic personnel are subject to the special law Higher Education Law No. 2547 and Higher Education Personnel Law No. 2914, while administrative personnel are subject to the Civil Servants Law No. 657, which is the framework law. This difference; Criminal investigations may deepen from time to time due to some legal problems experienced in the processes following the subjects such as disciplinary superiors and disciplinary boards and cause the concept of justice to be damaged. However, the resolution of disciplinary law problems experienced by disciplinary superiors and disciplinary boards in higher education institutions; It is also of great importance in terms of social peace and institutionalization, in ensuring public order and workplace order, especially in the establishment of justice.

When the studies on disciplinary investigations and disciplinary punishments and the decisions of the Council of State are examined, it is seen that there are errors and deficiencies in disciplinary investigations in general. In addition it has been determined that in disciplinary investigations, incompetent investigators who do not know the current legislation well are assigned. In this context, the most basic point that encourages researchers to do this study is the need to conduct a detailed situation analysis about the legal problems experienced by disciplinary superiors and disciplinary boards in terms of disciplinary law in higher education institutions. Determining the problems within the scope of situation analysis and presenting solutions for these problems is the starting point and main purpose of the study.

In terms of disciplinary law in higher education institutions, the legal problems experienced by disciplinary superiors and disciplinary boards cause many negative results, both material and moral. In the study, it is aimed to determine the situation about the problems that arise in terms of disciplinary law in higher education institutions and to offer solutions for these problems. Thus, the research proceeded on the basis of a descriptive analysis aiming to understand and define the 
problems experienced in disciplinary superiors and disciplinary boards in higher education institutions.

According to the findings obtained as a result of the research, the disciplinary legal knowledge of the disciplinary superiors and disciplinary boards members became the prominent concept. Although the majority of disciplinary superiors in higher education institutions are experts in their fields, they have not received any disciplinary law training. They encounter problems in this direction and try to overcome these problems with the experience they have gained over time, by improving themselves personally, and by getting support from the legal department. At the same time, although disciplinary investigations require knowledge of disciplinary law, the constant change in legislation makes it necessary to follow current changes. The fact that procedural errors stand out in the reasons for the deterioration of the decisions made as a result of the investigation also shows that insufficient knowledge of disciplinary law may be effective. The findings are similar to the prominent issues in the studies and the decisions of the Council of State.

When evaluated in general, the problems experienced by disciplinary superiors can be summarized as follows:

(1) Disciplinary law legislation changes frequently.

(2) Managers mostly learn disciplinary law by trial and error.

(3) Disciplinary superiors cannot find qualified investigators trained in disciplinary law.

(4) Procedural errors are mostly encountered in investigation reports. The lack of knowledge of the procedural legislation is the most important reason for errors.

(5) A causal link cannot be established between the alleged action by the investigators and the suspect.

(6) Proposing a penalty without giving any justification for the investigation,

(7) Failure to establish a link between the subject of the investigation and the proposed legal outcome,

(8) Failure to pay attention to the statute of limitations,

(9) Managers have not received training on disciplinary law,

(10) Lack of resources and examples in the field of disciplinary law,

(11) Preparation of disciplinary investigation report based on incomplete examination 
(12) These are the problems faced by disciplinary superiors in imposing disciplinary punishment.

Solution proposals;

(1) The disciplinary law legislation is monitored by the Investigation and Evaluation Commission (IEC) directly affiliated to the rector to be established at the university level and informing the relevant units,

(2) Administrative and academic administrators working in the units within the university are given in-service training on disciplinary law by IEC members,

(3) Training of investigators who can be assigned as investigators throughout the university by the IEC,

(4) In order to avoid procedural errors, which are frequently seen in the investigation reports, the investigation reports are submitted to the IEC after they are completed and examined and implemented after this examination,

(5) The control of the establishment of a causal link between the accused and the perpetrator in terms of the structural elements of the crime is carried out by the IEC,

(6) While revealing the cause and effect relationship in the investigations, the IEC should check whether the reason is written or not,

(7) Again, the IEC checks whether the realization status of the elements in the legal description of the act committed between the subject of the investigation and the conclusion is written,

(8) Following the investigations and making necessary warnings to the investigators according to a software program to be made by the legal consultancy in order not to be overstepped in the investigation process,

(9) Using distance education channels in universities to ensure that managers receive training on disciplinary law,

(10) Sharing the current legislation, sample report and files with the bulletin to be prepared by the IEC on disciplinary law and investigations.

(11) IEC should be the guide and support in case of preparing a disciplinary investigation report based on incomplete examination.

(12) Disciplinary superiors should seek the opinion of IEC in imposing disciplinary punishment.

The problems experienced in the disciplinary boards can be summarized as follows: 
(1) Lack of knowledge of the board members about the file,

(2) Incomplete understanding of the duty of rapporteur,

(3) Different perception of the nature of the Board's decision,

(4) The members of the Board are hesitant to express their opinions,

(5) Discussion of the investigation files in non-commissioned boards,

(6) Confusing the concepts of decision and objection in boards,

(7) Confusing special cases such as FETO files with other disciplinary proceedings,

(8) Not inviting a union representative to the Board meetings,

(9) Board members have not received training in the field of disciplinary law,

(10) Frequent changes in the members of the Board can be cited among these problems.

The suggestions to be presented to solve the problems experienced in the disciplinary boards can be listed as follows:

(1) The files discussed in the disciplinary boards should be summarized on an A4 paper by the rapporteurs and distributed to the board members in advance.

(2) Members who will undertake the duty of rapporteur in the boards should be subjected to inservice training by the IEC in terms of their duties and responsibilities.

(3) Decisions made by the boards must be implemented after the evaluation of the IEC.

(4) Each board member should have an obligation to express their views during the discussion of the file.

(5) Before the investigation files are entered into the boards, the IEC should check whether the correct board has entered its jurisdiction.

(6) In particular, the presence of a member of the IEC in the university disciplinary committee is important in terms of taking decisions in accordance with the law and correctly evaluating the objections made to the board.

(7) FETO investigations should not be considered as a normal investigation, but should be demonstrated as a separate practice.

(8) It is important to invite the union representative of whom the suspect is a member to the Board meetings. Because unions have an important role in defending personal rights. 
(9) Board members should be given in-service training by the IEC on disciplinary and criminal law.

(10) The members of the Board should not be changed frequently, except in cases of necessity, in order to ensure the continuity of justice.

In conclusion; disciplinary superiors, disciplinary investigators and disciplinary boards have the most important share in the compliance of disciplinary investigations with the law. However, the fact that disciplinary superiors, disciplinary investigators and members of disciplinary boards are not trained in disciplinary law and do not have sufficient knowledge and experience emerges as an important problem. In the solution of this problem, in-service trainings to be carried out by experts in appropriate times and environments for public officials who fulfill these duties will have an important share. In addition, the establishment of an Investigation and Evaluation Commission (IEC), which is directly affiliated with the rector and has advisory-coordination-control duties, especially in universities, will assume an important function in terms of minimizing procedural errors in the investigation files, making up for the deficiencies and unity of practice. 